\title{
Evaluation of Tubular Reactor Designs for Supercritical Water Oxidation of U.S. Department of Energy Mixed Waste
}

Charles M. Barnes

Published December 1994

Idaho National Engineering Laboratory Lockheed Idaho Technologies Company Idaho Falls, Idaho 83415 


\section{DISCLAIMER}

This report was prepared as an account of work sponsored by an agency of the United States Government. Neither the United States Government nor any agency thereof, nor any of their employees, make any warranty, express or implied, or assumes any legal liability or responsibility for the accuracy, completeness, or usefulness of any information, apparatus, product, or process disclosed, or represents that its use would not infringe privately owned rights. Reference herein to any specific commercial product, process, or service by trade name, trademark, manufacturer, or otherwise does not necessarily constitute or imply its endorsement, recommendation, or favoring by the United States Government or any agency thereof. The views and opinions of authors expressed herein do not necessarily state or reflect those of the United States Government or any agency thereof. 


\section{DISCLAIMER}

Portions of this document may be illegible in electronic image products. Images are produced from the best available original document. 


\section{Evaluation of Tubular Reactor Designs for Supercritical Water Oxidation of U.S. Department of Energy Mixed Waste}

INEL-94/0223

Prepared by

CMBame

C. M. Barnes, Senior Engineering Specialist

Chemical and Process Engineering

Reviewed by

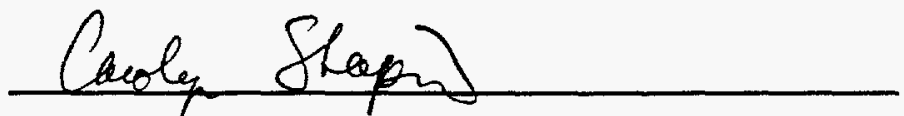

C. Shapiro, Engineering Specialist

Mechanical Engineering

Approved by

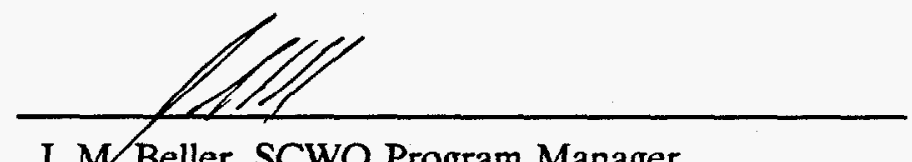

J. M. Beller, SCWO Program Manager

Waste Technology Development
$12-21-94$

Date

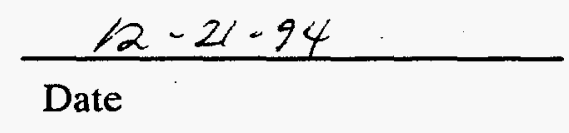




\begin{abstract}
This report is a review and evaluation of tubular reactor designs for supercritical water oxidation of U.S. Department of Energy mixed waste. Tubular reactors are evaluated against requirements for treatment of U.S Department of Energy mixed waste. Requirements that play major roles in the evaluation include achieving acceptable corrosion, deposition, and heat removal rates. A general evaluation is made of tubular reactors and specific reactors are discussed. Based on the evaluations, recommendations are made regarding continued development of supercritical water oxidation reactors for U.S. Department of Energy mixed waste.
\end{abstract}





\section{SUMMARY}

Supercritical water oxidation (SCWO) is an emerging technology for industrial waste treatment and is being developed for treatment of the U.S. Department of Energy (DOE) mixed hazardous and radioactive wastes. In the SCWO process, wastes containing organic material are oxidized in the presence of water at conditions of temperature and pressure above the critical point of water, $374^{\circ} \mathrm{C}$ and $22.1 \mathrm{MPa}$. DOE mixed wastes consist of a broad spectrum of liquids, sludges, and solids containing a wide variety of organic components plus inorganic components including radionuclides.

Requirements for a reactor treating DOE mixed wastes come from environmental regulations, waste characteristics, and cost and safety criteria. Environmental regulations set requirements for the destruction efficiency, which in turn set requirements on the temperature and residence time in the reactor. The halogens, sulfur, and phosphorus present in the waste feeds result in a highly corrosive environment that must be well controlled to minimize both maintenance on radioactively contaminated equipment as well as costs and wastes from replacing the reactor and other components of the process.

The radionuclides in the waste underscore the requirement for minimal wastes from the process, wastes in an easily disposal form, and avoidance of deposition of solids in the process. Because of the many competing technologies being developed to treat DOE mixed waste, process costs are expected to be an important factor in the selection of which technologies will be used for eventual treatment. It is estimated that in order to be competitive, a SCWO process will need to treat waste at a concentration of 10-15\% organics. The estimated capacity for a full-scale SCWO unit treating DOE mixed waste is 5,000 gpd of waste plus. water.

At present, there does not appear to be economic means of controlling corrosion or deposition in tubular reactors for wastes similar to DOE mixed wastes. Control of corrosion by dilution is expected to be economically infeasible because, for wastes such as TRIM®SOL, a dilution factor of 300 is required. Test data for high-nickel alloys with highly chlorinated feeds have shown unacceptable corrosion rates. Because a full-scale reactor is expected to be hundreds of feet in length, corrosion resistant coatings or liners would be difficult to fabricate and maintain. Control of corrosion by in situ neutralization would likely result in high rates of salt deposition leading to plugging tubular reactors or other components in the process.

Many tubular reactor designs depend on high velocities to avoid deposition of particles in the reactor. However, to avoid deposition of high density compounds present in DOE waste, such as heavy metal salts, small diameter tubes are required. To achieve the required residence time in small diameter tubes, a reactor length of hundreds of feet is needed. Such long reactors could result in high capital costs or operational difficulties in a nuclear facility. The principles of keeping solids from depositing by high velocities also have not been demonstrated at the conditions of supercritical water oxidation, and some data to the contrary has been obtained.

Other approaches to deposition in SCWO reactors include redissolution and mechanical removal. Redissolution of deposited material would add considerably to the total effluent volume and mechanical techniques have not been demonstrated. 
Problems of temperature control or inadequate heat transfer are expected for tubular designs for feeds with $10-15 \%$ organics. The high rate of heat release from oxidation reactions cannot by balanced by preheating feed streams in annular reactor designs and would require mechanically complicated designs if coolant fluids were used. Heat control through dilution is unworkable because of the wide range of feedstock compositions, which will result in variations in kinetics from waste to waste. Because of heat transfer limitations, annular reactors cannot process waste at the organic concentrations required for treatment of DOE waste.

Due to problems with tubular reactors in the areas of corrosion, deposition, and heat transfer for feeds of high organic concentrations, it is recommended that development of SCWO reactors for DOE mixed wastes be focused on other reactor types, such as the vessel reactor and porous wall reactor. 


\section{CONTENTS}

ABSTRACT $\ldots \ldots \ldots \ldots \ldots \ldots \ldots \ldots \ldots \ldots \ldots \ldots \ldots \ldots \ldots \ldots \ldots \ldots \ldots \ldots \ldots \ldots$

SUMMARY $\ldots \ldots \ldots \ldots \ldots \ldots \ldots \ldots \ldots \ldots \ldots \ldots \ldots \ldots \ldots \ldots \ldots \ldots \ldots$

1. INTRODUCTION $\ldots \ldots \ldots \ldots \ldots \ldots \ldots \ldots \ldots \ldots \ldots \ldots \ldots \ldots \ldots \ldots \ldots \ldots$

2. TUBULAR REACTOR DESCRIPTIONS $\ldots \ldots \ldots \ldots \ldots \ldots \ldots \ldots \ldots \ldots \ldots$

3. GENERAL EVALUATION OF TUBULAR REACTORS $\ldots \ldots \ldots \ldots \ldots \ldots \ldots \ldots$

3.1 Design Basis and Requirements ...................... 10

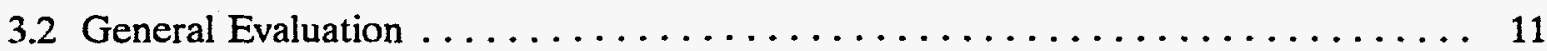

4. EVALUATION OF SPECIFIC REACTOR DESIGNS $\ldots \ldots \ldots \ldots \ldots \ldots \ldots \ldots \ldots$

4.1 Modec Constant Diameter Tubular Reactor $\ldots \ldots \ldots \ldots \ldots \ldots \ldots$

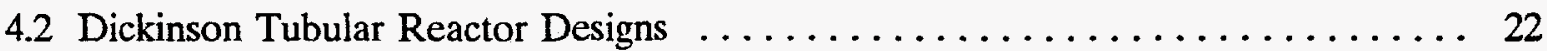

4.3 Welch and Slegwarth Annular Reactor $\ldots \ldots \ldots \ldots \ldots \ldots \ldots \ldots \ldots$

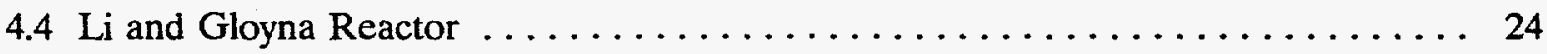

4.5 Other Tubular Reactor Designs $\ldots \ldots \ldots \ldots \ldots \ldots \ldots \ldots \ldots \ldots \ldots \ldots$

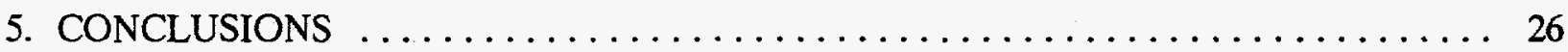

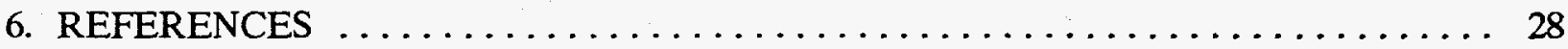

Appendix A - Estimate of Waste Concentration for an Economic Supercritical Water

Oxidation Plant $\ldots \ldots \ldots \ldots \ldots \ldots \ldots \ldots \ldots \ldots \ldots \ldots \ldots \ldots \ldots \ldots \ldots \ldots \ldots \ldots$

Appendix B - Basis for Estimate of Required Reactor Residence Time $\ldots \ldots \ldots$. . . B

Appendix $\mathrm{C}-$ Method Used in Critical Velocity Calculations $\ldots \ldots \ldots \ldots \ldots \ldots \ldots$ 


\section{Evaluation of Tubular Reactor Designs for Supercritical Water Oxidation of U.S. Department of Energy Mixed Waste}

\section{INTRODUCTION}

Supercritical water oxidation (SCWO) is an emerging technology for industrial waste treatment and is being developed for treatment of the U.S. Department of Energy (DOE) mixed hazardous and radioactive wastes. In the SCWO process, wastes containing organic material are oxidized in the presence of water at conditions of temperature and pressure above the critical point of water, $374^{\circ} \mathrm{C}$ and $22.1 \mathrm{MPa}$. Several reviews of SCWO technology have been published. ${ }^{1-8}$

This study is a review and evaluation of tubular reactor designs for SCWO of DOE mixed waste. DOE mixed wastes consist of a broad spectrum of liquids, sludges and solids containing a wide variety of organic components plus inorganic components including radionuclides. In most cases the wastes are not well characterized.

Neither is the waste homogeneous. The waste is presently contained in tens of thousands of individual containers, mostly 55 -gal drums, stored at more than a dozen sites across the country. In addition to the stored mixed waste, mixed waste will continue to be generated by DOE laboratories in research, development, production, and environmental restoration activities.

To evaluate SCWO technology for treatment of DOE mixed wastes, 10 simulated waste streams have been defined. ${ }^{9}$ These simulated wastes do not envelop the full range of DOE mixed wastes, but are intended to provide a basis for the design and evaluation of SCWO pilot plants. The 10 wastes include the following:

1. A mixture of benzene, biphenyl, diphenylamine, phenol and diphenyl mercury

2. A mixture of methanol, acetone, Resource Conservation and Recovery Act (RCRA)hazardous metals in the form of acetates or oxides, and radionuclide surrogates

3. A mixture of combustible solids, including lab coats, plastics, latex gloves, cardboard, Kimwipes, filter paper, paper towels, and wood

4. The cutting fluid Trim ${ }^{\otimes}$ Sol with acetates of nonhazardous, RCRA-hazardous, and radionuclide surrogate metals added

5. A mixture of ethylene glycol, ethanolamines, boric acid, and motor oil

6. Activated carbon with salts or acetates of aluminum, calcium, fluorine, iron, nickel, potassium, silicon, sodium, and sulfur added

7. Two commercial scintillation fluids 
8. A mixture of tributyl phosphate, dibutyl phosphate, and paraffinic hydrocarbon diluent

9. A mixture of halogenated solvents and Freon with RCRA-hazardous metals and radionuclide surrogates added

10. A sludge of calcium silicate, Oil Dri, ethylene glycol, Texaco Regal oil, carbon tetrachloride, trichloroethane, and beryllium.

Selected properties of the above-simulated wastes are shown in Table 1.

This study evaluates tubular reactors for SCWO of DOE mixed waste. The evaluation is based upon a review of the design and performance of tubular reactors in published literature and limited to this information. A previous study compared all types of reactors for SCWO. ${ }^{10}$ Porous wall reactors, although they can be considered tubular reactors, are not considered in this study.

Table 1. Selected properties of undiluted DOE simulated wastes.

\begin{tabular}{|c|c|c|c|c|c|c|c|}
\hline \multirow[b]{2}{*}{ Waste } & \multirow{2}{*}{$\begin{array}{l}\text { Heating } \\
\text { value } \\
\text { (Btu/lb) }\end{array}$} & \multirow{2}{*}{$\begin{array}{c}\text { Organic } \\
\text { solids } \\
(\%)\end{array}$} & \multirow{2}{*}{$\begin{array}{c}\text { Inorganic } \\
\text { solids } \\
(\%)\end{array}$} & \multicolumn{4}{|c|}{ Acid gas precursors } \\
\hline & & & & $\mathrm{Cl}$ & $\mathbf{P}$ & S & $\mathrm{F}$ \\
\hline Aromatics & 17,450 & - & - & - & - & - & - \\
\hline Solvents & 10,800 & - & 6.1 & - & - & - & - \\
\hline Combustibles & 9,500 & 100 & - & $1.2 \%$ & - & - & 一 \\
\hline TRIM๑SOL & 15,000 & - & 0.8 & $11 \%$ & - & $2 \%$ & - \\
\hline Mixed oils & 9,800 & - & - & - & - & - & - \\
\hline Carbon & 14,090 & 92.3 & 7.7 & - & - & - & 90 ppm \\
\hline Scintillation fluid & 17,860 & - & - & - & - & $0.95 \%$ & $0.6 \%$ \\
\hline $\begin{array}{l}\text { Tributyl } \\
\text { phosphate }\end{array}$ & 15,670 & - & 一 & - & $6 \%$ & - & - \\
\hline $\begin{array}{l}\text { Halogenated } \\
\text { solvents }\end{array}$ & 1,090 & - & 4 & $85 \%$ & - & - & - \\
\hline Sludge & 6,100 & - & 33 & $18 \%$ & - & - & - \\
\hline
\end{tabular}




\section{TUBULAR REACTOR DESCRIPTIONS}

Several types of tubular reactors are described in the patent literature for SCWO. A double pipe or annular reactor is described in a patent issued to J. F. Welch and J. D. Slegwarth. ${ }^{11}$ A patent issued to N. L. Dickinson contains designs for both annular reactors and a U-tube configuration. ${ }^{12}$ An annular reactor using sintered separators has been patented by $\mathrm{Li}$ and Gloyna. ${ }^{13}$ Tubular reactors with "substantially constant diameter" of several configurations are discussed in a patent issued to M. Modell. ${ }^{14}$ Tubular reactors have been tested by Modar, Modec, Sandia National Laboratories, Los Alamos National Laboratory, and the University of Texas.

Dickinson's patent covers a process for combustion of solid fuels in water at conditions of pressure and temperature that extend into the supercritical range. Claims do not explicitly cover a reactor design beyond "an elongated combustion reactor," and the patent allows for substituting other reactor types for the tubular reactors that are considered preferred embodiments. These tubular configurations are shown in Figure 1. In two of the configurations, the reactor is jacketed, and heat from the reaction is transferred to either feed air or feed fuel, which is in slurry form. The third configuration, shown in Figure $1 \mathrm{C}$, is designed for an internal recycle of reactor effluent into the reactor feed. In each of the three configurations, cool water or recycle ash slurry is added at one or more intermediate points in the reactor to cool the reactor mixture and complete oxidation.

The Dickinson process is designed for relatively high fuel to water ratios. According to the patent, a 1:1 coal-to-water ratio is realistic, while ratios higher than 3:1 and lower than 1:10 coal to water may not be economic. The patent also mentions that fibrous fuels such as wood and agricultural wastes require a slurry to water ratio lower than $1: 1$ fuel to water. With these fuel-towater ratios, heat must be removed from the reactor to avoid exceeding temperature limits of reactor materials. The method used in the Dickinson patent for controlling temperature in the reactor is through recycling of cooled ash slurry (reactor effluent) or the addition of cool water at one or more intermediate points in the reactor. To both promote oxidation and neutralize sulfuric acid formed from sulfur in coal, an alkali is added to the feed slurry. Dickinson's patent covers both horizontal and vertical tubular reactors, arranged as single or multiple trains, or comprised of multiple reactor sections connected by 180-degree bends. A reactor temperature in the range of $1000-1300^{\circ} \mathrm{F}\left(540-700^{\circ} \mathrm{C}\right)$ is preferred.

A sketch of a reactor described in the Welch and Slegwarth patent ${ }^{11}$ is shown in Figure 2. Like the Dickinson patent, an SCWO process rather than a reactor design is patented, but a tubular reactor is shown as a preferred embodiment. The patent lists a wide variety of candidate feed streams, including waste solvents, wastewaters, nerve gases, bacteriological warfare agents, hazardous waste slurries and sludges, out-of-specification oils, and polychlorinated biphenyl (PCB)-contaminated mineral oils. In this design, waste, water, and a nongaseous oxygen source are mixed together and preheated in an annular space of the reactor through heat exchange with reactor effluent in the inner tube. The final section of the reactor preheater is heated by an external source. The fluid then reverses direction, passes into the inner tube that is the reaction section. Following reaction, the effluent is cooled in the same tube by exchanging heat with incoming feed. 


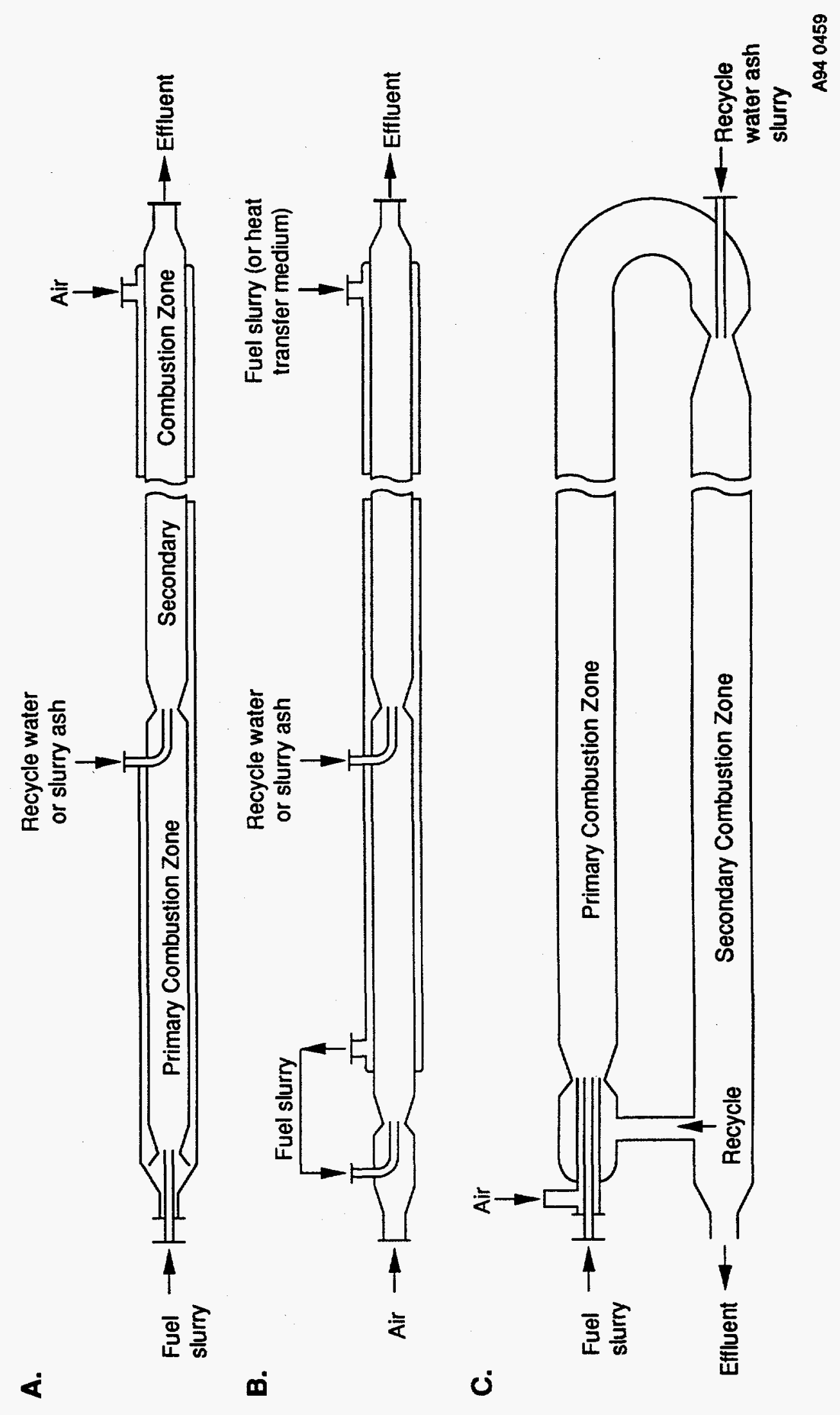

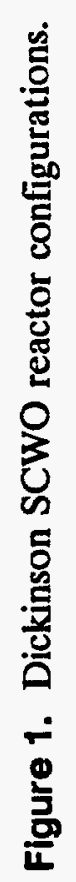




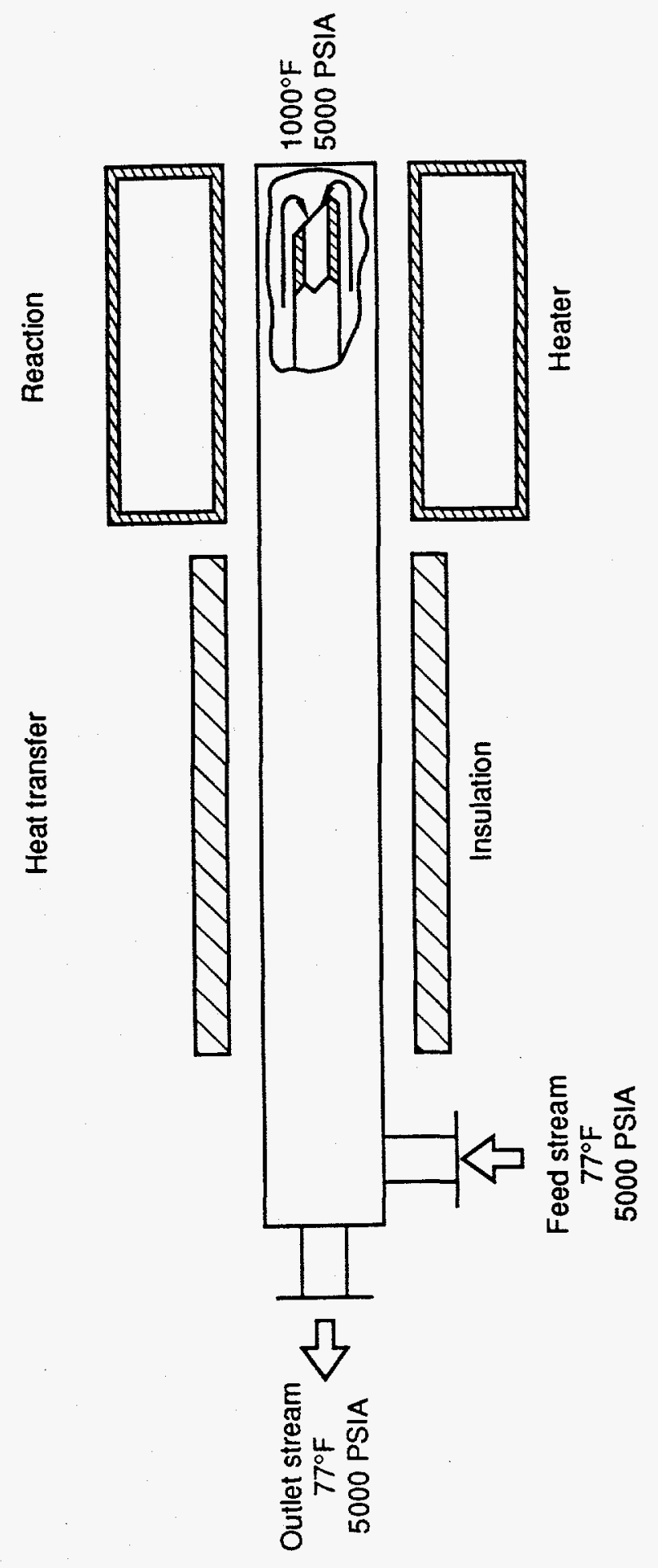

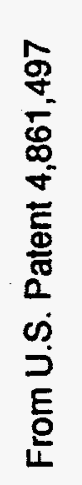

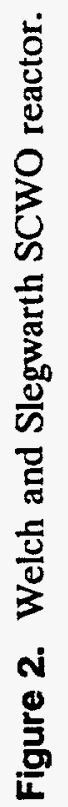


A sketch of the $\mathrm{Li} /$ Gloyna reactor ${ }^{13}$ is shown in Figure 3. Hot recycle water and oxidant enter the annulus of the reactor separately and are heated by exchange of heat with the reaction fluid in the inner tube. The waste feed is added at an intermediate point in the reactor so that it can be quickly brought up to reaction temperature. Fluid from the annulus enters the inner pipe through a porous filter. If the reactor is vertical, as shown in Figure 3, large particles are expected to fall off the filter to be collected in the bottom of the reactor. Fluid that passes through the filter, flows up through the inner tube where reaction occurs, and then moves into a cooling section. Heat is removed from the effluent in the cooling section by an external coolant in the annulus. Within the cooling section is a means to separate gases from the condensed liquid, a portion of which is recycled to the reactor.

Modell has patented both an SCWO process and apparatus for his process, including a tubular reactor. ${ }^{14}$ Sketches of several configurations of his reactor design are shown in Figures 4 and 5. The Modell design incorporates a preheater, reactor and cooler in a tube of "substantially constant internal diameter". In the configurations shown in Figure 4, water, organic feed, and oxygen are mixed and heated electrically to a temperature greater than $250^{\circ} \mathrm{C}$. This is followed by a reaction section and one or more cooling sections in which a heat transfer fluid is used as a cooling medium. With the configuration of Figure $4 \mathrm{~A}$, waste can be processed with a heating value of a maximum of about $2,300 \mathrm{~kJ} / \mathrm{kg}(1,000 \mathrm{Btu} / \mathrm{lb})$, according to the patent. Feeds with higher heating values will produce reaction temperatures higher than reactor materials can withstand, and cooling of the reaction section is recommended, such as configuration Figure 4B. Still additional configurations of the Modell tubular reactor, shown in Figure 4, include heat transfer between feed and effluent through a heat-conducting element or a heat-transfer fluid.

The Modell reactor is designed to process aqueous mixtures of organic plus inorganic materials. The designs described in the patent have several features or design requirements aimed at avoiding the problem of deposition of inorganic materials. Having a "substantially constant internal diameter from inlet to outlet" eliminates flow stagnation areas where deposits could collect. The reactor diameter is kept small enough to cause fluid velocities in excess of the critical velocity needed to keep solids in suspension. Methods to remove deposited solids are also claimed in the invention, including brushing, spraying, and use of a scale-inhibiting magnet. 


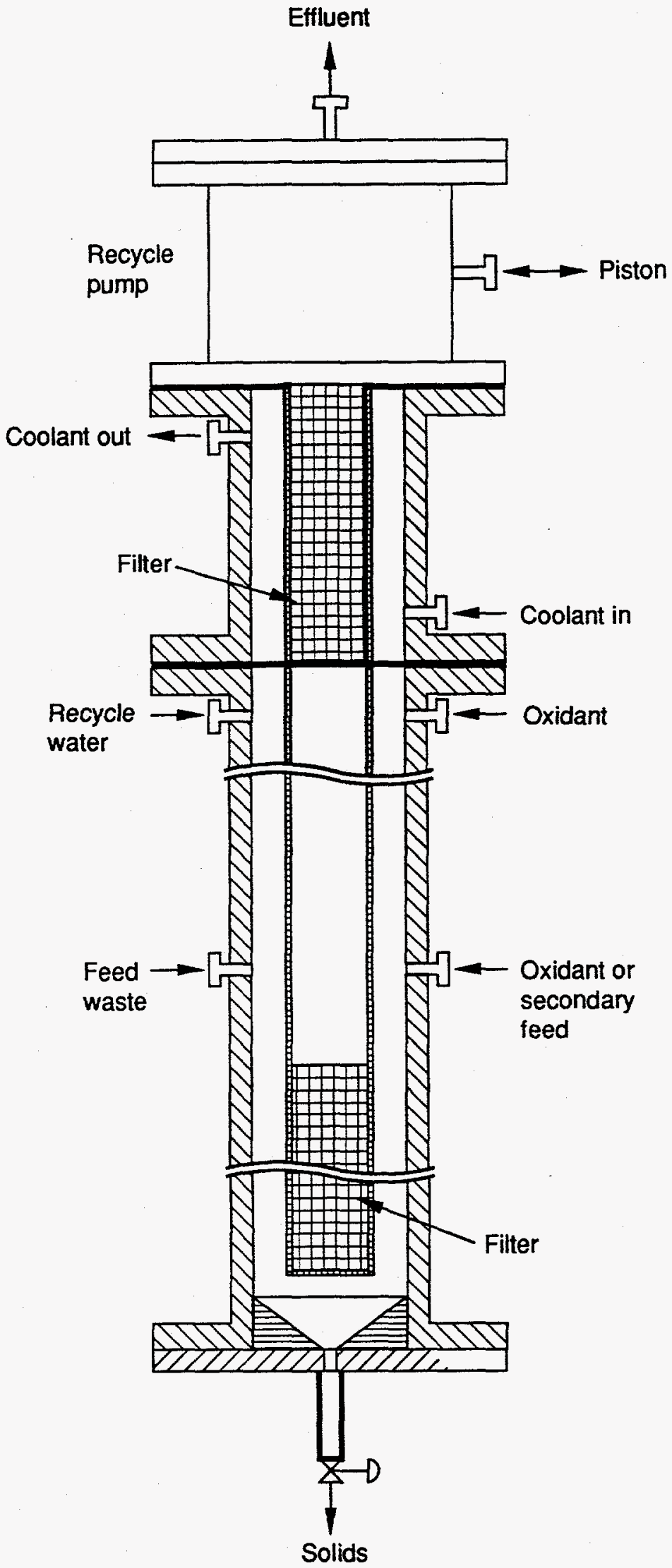

Figure 3. Li/Gloyna CWO reactor from International Patent Application PCT/US92/06459. 

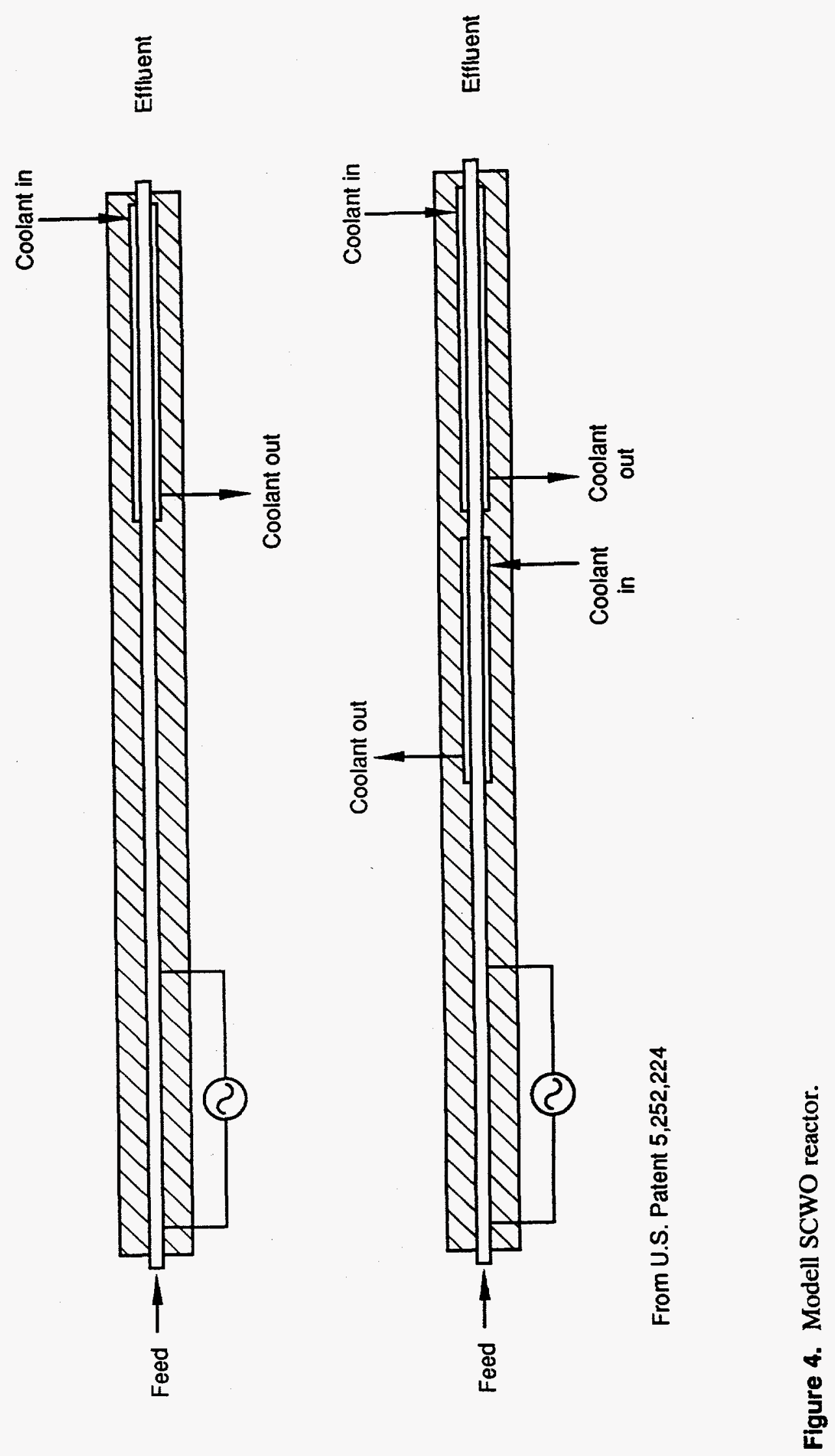

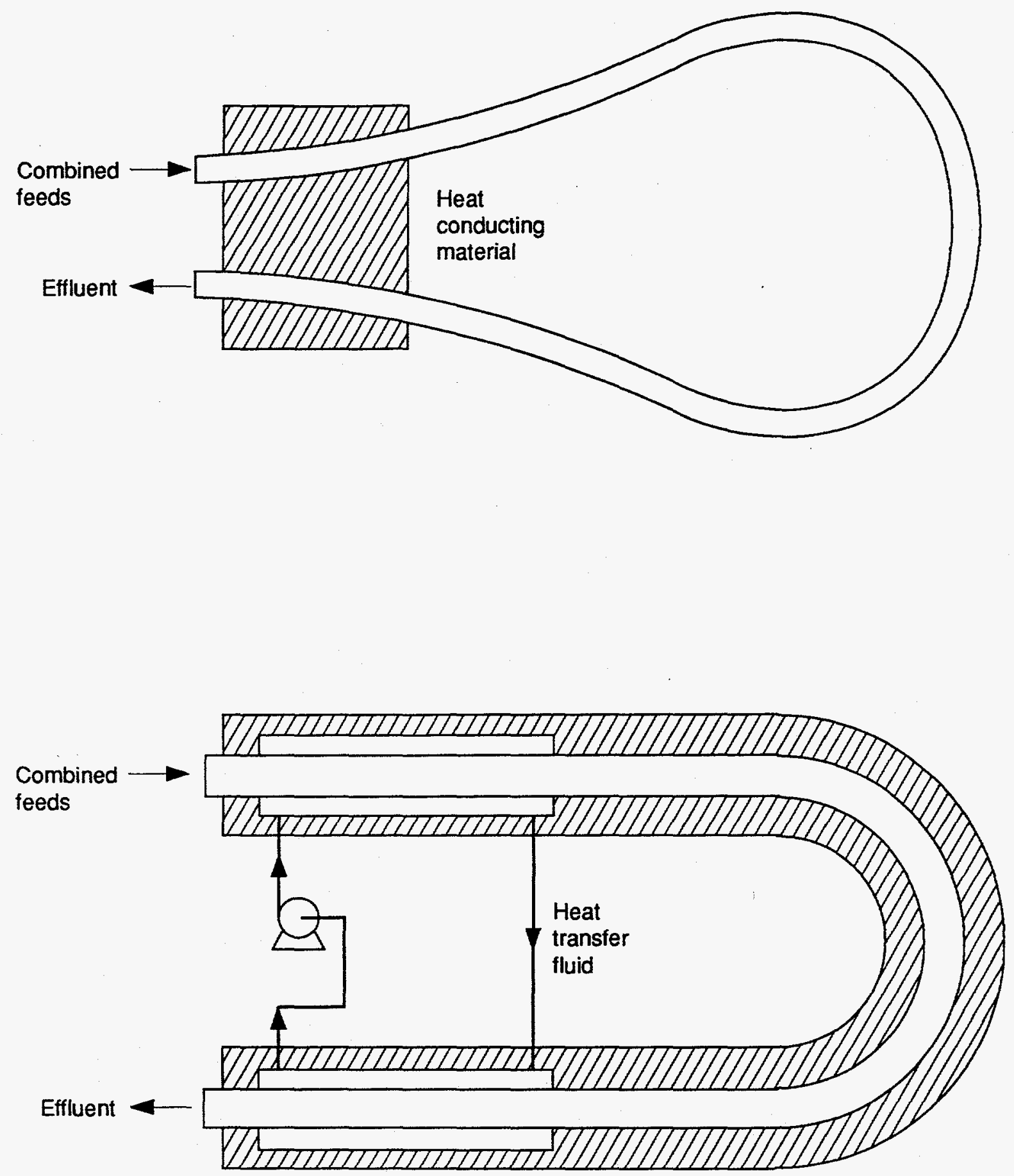

X94 0530

Figure 5. Additional Modell SCWO reactor configuration from U.S. Patent 5,252,224. 


\section{GENERAL EVALUATION OF TUBULAR REACTORS}

Considerable testing has been performed in tubular SCWO reactors. However, it is important to understand the difference between the units that produced this data and the requirements for a full-scale unit. A high percentage of the existing data is from laboratory or bench-scale units, typically with a capacity of about $1 \mathrm{gph}$. A full-scale DOE facility will need to have a capacity more than two orders of magnitude greater than this. Second, the test data have mostly been from dilute concentrations of waste, typically less than $2 \%$. In order to be economically competitive with technologies that can treat waste without dilution, it is estimated that a full-scale SCWO unit must treat waste at concentrations of 10-15\% organic material (see Appendix A). Third, DOE wastes represent a wide range of waste forms and compositions that add flexibility requirements that are usually not considered in laboratory systems. Fourth, most bench-scale data are for runs of a duration of only a few hours or less, while a full-scale plant will need to operate continuously for days. Finally, while some test data have been obtained on SCWO of simulated wastes with radionuclide surrogates, no data have been published on treatment of actual radioactive waste.

\subsection{Design Basis and Requirements}

Requirements for a reactor treating DOE mixed wastes come from environmental regulations, waste characteristics, and cost and safety criteria. While uncertainties and unknowns exist because of inadequate waste characterization, limited pilot-scale test data, and limited fundamental understanding of chemistry at the conditions of SCWO, a basis can be established for making a general evaluation of reactors. The reactor residence time must be sufficient to achieve high destruction efficiencies for a wide variety of organic materials. Based on kinetics, which have been determined for SCWO of only about a dozen organic compounds, a residence time of at least 30 seconds is required for a $99.99 \%$ destruction efficiency at $550^{\circ} \mathrm{C}$ (see Appendix B). To allow for the wide range of waste compositions, the reactor should be able to operate at up to at least $600^{\circ} \mathrm{C}$.

Test data have shown that reactor pressure only marginally affects conversions. For conversion of organics an operating pressure of 3,500 psia is assumed. However, when inorganics are present in the feed or formed in the reaction, a higher pressure may be required to keep inorganic materials dissolved in the supercritical water phase. To allow some flexibility for the various wastes with inorganics, a tentative maximum pressure of 5,000 psia is selected.

Based on the volume of DOE mixed waste, an estimate of the amount that could be treated by a reasonable number of SCWO units, a 5-year treatment schedule, and a reasonable scale-up capacity from present pilot plants, the design basis flow rate is $\mathbf{5 0 0}$ gpd of undiluted organic waste. Based on economic factors (see Appendix A), water-diluted waste should have an concentration of approximately $10-15 \%$ organic, averaged over all wastes treated. The goal is to seek the economic advantage of high organic throughput without exceeding temperature limitations of reactor materials. A $10 \%$ organic feed concentration would be equivalent to an SCWO reactor capacity of 5,000 gpd. 
As seen in Table 1 the heat content of the undiluted wastes varies from $1090 \mathrm{Btu} / \mathrm{lb}$ to nearly $18,000 \mathrm{Btu} / \mathrm{lb}$. To maintain relatively constant duty requirements and temperature profiles, the waste concentration can be adjusted from waste to waste and in some cases wastes may be blended. Thus, the concentration for certain wastes may fall outside the 10-15\% organic range. A 10-15\% organic feed concentration corresponds to a water-diluted feed heat content of about $1,000-1,800 \mathrm{Btu} / \mathrm{lb}$, based on higher dilution of high heat content wastes and lower dilution of lower heat content wastes, and the average of all wastes would be expected to fall in this range. At this level of heat content, heat removal from the reactor will be required.

The halogens, sulfur, and phosphorus present in the waste feeds result in a highly corrosive environment that must be well controlled to minimize both maintenance on radioactively contaminated equipment as well as costs and wastes from replacing the reactor and other components of the process. The radionuclides in the waste underscore the requirement for minimal wastes from the process, wastes in an easily disposal form, and avoidance of deposition of solids in the process.

A full-scale SCWO plant, including the reactor, will need to be able to operate 24 hours per day to avoid long heat-up/cool-down times as well as avoid wear on equipment from thermal cycling. A stream factor of at least 200 days per year is required to meet the production schedule typical of DOE plants. The reactor will need to be integrated in a treatment process that will be economically feasible and competitive with alternative treatment processes. ${ }^{a}$ To reduce the total gaseous effluent release, oxygen is selected over air as the oxidant.

\subsection{General Evaluation}

Requirements for residence time, capacity, temperature, and pressure can be met by designing a tubular reactor with an appropriate diameter, length, and wall thickness. The resulting dimensions, combined with specified materials of construction, become one component in the reactor cost estimate. Requirements for operating life and economic feasibility and competitiveness thus become the major evaluation criteria for tubular reactors compared to other types of reactors, or of one tubular design compared to another. For DOE wastes, the two major factors upon which operating life and economic feasibility depend are corrosion and solids deposition.

Corrosion and deposition have been identified as the two major issues in the technical and economic feasibility of SCWO. ${ }^{4}$ Test data have consistently demonstrated that high destruction efficiencies can be achieved in tubular or other types of reactors. ${ }^{1,2}$ However, testing with feeds containing high levels of acid gas precursors have consistently resulted in high levels of corrosion. $^{2,3,7,15-20}$ In tests with some types of solids, high rates of deposition or plugging have been seen (see footnote b). ${ }^{13,14,20-24}$ High corrosion rates would be detrimental to a mixed waste

a. For descriptions and comparisons of alternative treatment technologies for DOE mixed waste, see F. Feizollahi and W. J. Quapp, Integrated Thermal Treatment System Study, Phase 1 Results, July 1994, and Draft Phase 2 Results, August 1994, EGG-MS-11211.

b. Personal communication with Glenn Hong, October 19, 1994. 
facility in several ways. Frequent replacement of equipment or equipment parts would be expensive, increase workers exposure to radioactively contaminated equipment, and add to the total waste from the treatment process. Corrosion could result in contaminating the final process waste, which otherwise would not be hazardous, with a RCRA-hazardous material, usually chromium. Corrosion products would add to maintenance required on downstream equipment as they could foul heat exchangers or plug let-down valves. Also, stress corrosion cracking could potentially cause catastrophic failure.

Minimizing deposition is important to reduce maintenance and down time when equipment plugs to maintain accountability of radionuclides and to avoid fouling of tube surfaces in the reactor, feed heater, or effluent exchanger that would lead to inadequate heat transfer rates.

Three general approaches to minimize corrosion in tubular SCWO reactors have been proposed or are being pursued-dilution, corrosion-resistant materials, ${ }^{3,15-19,25,26}$ and neutralization of acids. $1,3,12,27$

To achieve a concentration of $\mathrm{HCl}$ in the reactor that would be equivalent to a $\mathrm{pH}$ of 2 in condensed water, a dilution factor of 27.4 per wt $\% \mathrm{Cl}$ in the feed is required. Thus, for DOE simulated waste \#4, TRIM®SOL, which has $11 \mathrm{wt} \% \mathrm{Cl}$, a dilution factor of $11 \times 27.4$, or 300 , is required. For a chlorinated solvent waste such as simulated waste \#9, a dilution factor of 2,300 is required. Treatment of TRIMOSOL via dilution would thus take 20 times longer, or require a reactor sized for 20 times the capacity, than if the feed waste was only diluted to a heating value of $1,000 \mathrm{Btu} / \mathrm{lb}$.

The wide range of compositions of DOE wastes makes the search for corrosion-resistance materials very challenging at best and never ending at worst. Feeds range from acidic to neutral to basic, and upon reaction, can result in hydrofluoric acid, hydrochloric acid, boric acid, sulfuric acid, or phosphoric acid. Organic acids such as acetic acid are formed from some hydrocarbon feeds as intermediates, while organic nitrogen in other feeds results in ammonia as an intermediate or product. Other feeds contain salts that can be corrosive. Oxygen, which must be present at high concentrations in order to fully oxidize organics, likely accelerates corrosion reactions.

In many tubular reactor designs, the reactor, preheater, and effluent cooler are integrated. Thus, the material of construction for the integral reactor/preheater/cooler must withstand a temperature range from near ambient to $600^{\circ} \mathrm{C}$, over which a single feed will undergo at least one phase change as well as composition changes due to oxidation. Recently, specialists and researchers in SCWO corrosion came to the consensus that it is extremely unlikely that a universal material can be found that can perform in the preheater, reactor, and cooldown section of an SCWO system. ${ }^{17}$

Because of the wide range of composition of DOE mixed wastes, different types of corrosion would be expected. General corrosion, pitting, and stress corrosion cracking have all been identified in SCWO systems. ${ }^{17}$ While materials testing has been performed by several SCWO developers, most of this data is proprietary and has not been published. Thus, neither fundamental chemical understanding of corrosion at supercritical water conditions or materials test data are available to provide a basis for selection of materials for a full-scale tubular reactor 
for DOE wastes. The alloys used in bench-scale and pilot-scale systems, usually Hastelloy C-276 or Inconel 625 , have shown unacceptable corrosion rates when processing feeds with significant halogen or sulfur contents. ${ }^{3,15,25}$

Coatings or liners have also been used or suggested as means to minimize corrosion in SCWO reactors. $1,3,15,19$ The dimensions of a full-scale tubular reactor for treatment of DOE waste, roughly 1 -in. diameter by hundreds of feet long, make many types of coatings infeasible. Considerable testing would likely be required to find liners that would be corrosion resistant over the wide range of chemical environments that would be produced by SCWO of DOE wastes and also mechanically adequate. Liners are likely to add significant expense, many being of exotic materials, and may be difficult to fabricate or install in reactor designs that are coiled or have multiple bends. Their removal and replacement may prove problematic because liner materials and pressure boundary materials may deform differentially over many thermal cycles.

In situ neutralization is another alternative that has been proposed for control of corrosion, but has seen minimal testing in tubular reactors at the acid/salt concentrations required for DOE wastes. If neutralization is used to control corrosion, the reactor must be able to handle neutralization salts in concentrations on the order of at least $1-2 \%$. With in situ neutralization, deposition of salts leading to plugging of the reactor or downstream equipment may result. Also, the salts produced from in situ neutralization may themselves cause corrosion in certain regions of the reactor system.

Several methods to avoid deposition are discussed by Modell in U.S. Patent $5,252,224,{ }^{14}$ including maintaining a velocity in the tube greater than the critical velocity for settling of solid particles. Numerous relationships have been proposed for the prediction of critical velocities. One of the more recent formulations expresses the critical velocity as a function of the concentration of solids, particle density, fluid density, particle diameter, pipe diameter, fluid viscosity, and constants to correct for hindered settling and eddy velocity damping. ${ }^{28}$ The accuracy of this or any other correlation for solids in supercritical water is unknown.

If the correlation is assumed to be correct, then for a given mass flow rate, the critical velocity can be calculated, which then determines the tube inside diameter (ID). Knowing the diameter, the length can then be calculated from the residence time and mass flow rate.

Reactor sizes for various solids parameters are shown in Table 2 for an SCWO unit with a feed capacity of $5,000 \mathrm{gpd}$ of waste plus water.

As seen in Table 2, the particle concentration has a negligible effect on reactor sizing, particle size has a small effect, and particle density has a large effect. Very little data are available on particle size distributions for solids precipitating in supercritical water. Armellini, Hong, and Tester measured particle sizes $\mathrm{NaCl}$ and $\mathrm{Na}_{2} \mathrm{SO}_{4}$ when jets containing $3 \%$ salt were 
Table 2. Tubular reactor sizing based on critical velocity calculations.

\begin{tabular}{cccccc}
\hline $\begin{array}{c}\text { Solid } \\
\text { density } \\
(\mathrm{g} / \mathrm{cc})\end{array}$ & $\begin{array}{c}\text { Particle } \\
\text { size } \\
\text { (microns) }\end{array}$ & $\begin{array}{c}\text { Particle } \\
\text { concentration } \\
(\mathrm{wt} \%)\end{array}$ & $\begin{array}{c}\text { Maximum } \\
\text { inside } \\
\text { diameter } \\
\text { (in.) }\end{array}$ & $\begin{array}{c}\text { Actual } \\
\text { inside } \\
\text { diameter } \\
\text { (in.) }\end{array}$ & $\begin{array}{c}\text { Reactor } \\
\text { length } \\
(\mathrm{ft})\end{array}$ \\
\hline 2.68 & 40 & 1 & 1.27 & $1.16(1.5$ in. Sch 160) & 550 \\
2.68 & 40 & 0.1 & 1.27 & $1.16(1.5$ in. Sch 160) & 550 \\
2.68 & 40 & 10 & 1.26 & $1.16(1.5$ in. Sch 160) & 550 \\
2.68 & 10 & 1 & 1.41 & $1.34(1.25$ in. Sch 160) & 410 \\
2.68 & 100 & 1 & 1.20 & $1.16(1.5$ in. Sch 160) & 550 \\
1.16 & 40 & 1 & 1.70 & $1.69(2$ in. Sch 160) & 260 \\
5.7 & 40 & 1 & 1.07 & $0.90(1.5$ in. XX) & 910 \\
11.1 & 40 & 1 & 0.93 & $0.90(1.5$ in. XX) & 910 \\
11.1 & 10 & 0.1 & 1.03 & $0.90(1.5$ in. XX) & 910 \\
\hline
\end{tabular}

injected into a stream of supercritical water, and report that sodium chloride formed clusters with lengths between 10 and 100 microns and sodium sulfate from 1 to $>25$ microns. $^{c}$

Anhydrous sodium sulfate has a density of $2.68 \mathrm{~g} / \mathrm{cc}$, and most alkali and alkali earth salts have densities in the range of 2-3 g/cc. Hydrated salts have lower densities. Metal oxides have densities typically in the range of 5-7 g/cc and heavy metal and radionuclide oxides, such as mercury, uranium, and plutonium, have densities of $10-12 \mathrm{~g} / \mathrm{cc}$. The most prevalent radionuclides present in DOE waste are uranium and plutonium. While present in small quantities in most wastes, the radionuclide content is highly variable and can reach levels of tens of grams per 55-gal drum. To avoid deposition of radionuclides in an SCWO tubular reactor by maintaining a velocity to keep them in suspension would thus require a reactor of less than 1 in. ID. And for such a diameter, a length of $910 \mathrm{ft}$ is required to achieve the needed residence time. While long reactors are feasible, the capital costs associated with a nuclear facility may prove prohibitive. Configuring the reactor with 180-degree bends or as a coil still results in relatively large space requirements and may have sections more prone to deposition. These configurations would also complicate the design of the heat exchanger to remove heat from the reactor and present challenges for instrumenting the reactor.

The reactor sizes given in Table 2 are based on critical velocities in the reactor itself. Some solids such as sodium sulfate or phosphate precipitate at temperatures far below the reactor temperature, and thus, the preheater must be sized to maintain a velocity above the critical as

c. F. J. Armellini, G. T. Hong, J. W. Tester, "Precipitation of Sodium Chloride and Sodium Sulfate in Water from Sub- to Supercritical Conditions: $150^{\circ} \mathrm{C}$ to $550^{\circ} \mathrm{C}, 100$ to $300 \mathrm{Bar}$," submitted to Joumal of Supercritical Fluids, November 1993. 
well as the reactor. According to the theories presented in Reference 28 , the critical velocity is proportional to the tube diameter raised to the 0.46 power, the fluid density to the -0.54 power, and the difference in densities of the solid particles and the fluid to the +0.54 power. The velocity in a tube is also related to fluid density and tube diameter by the relationship

$m=(\pi / 4) D^{2} v \rho$

where

$$
\begin{aligned}
& \mathrm{m}=\text { mass flow rate } \\
& \mathrm{D}=\text { tube inside diameter } \\
& \mathbf{v}=\text { fluid velocity } \\
& \rho=\text { fluid density. }
\end{aligned}
$$

Combining this equation with the equation for critical velocity, one finds that to maintain critical velocity as the fluid density (temperature) changes, the tube diameter is proportional to $(\Delta \rho)^{-0.22} \rho^{-0.19}$, where $\Delta \rho$ is the difference between the density of the solid particles and the fluid. Because the diameter is inversely proportional to the fluid density, the diameter of the preheater, where the fluid density is higher than in the reactor because the temperature is lower, needs to be smaller than that of the reactor. Thus, if a single diameter tube is used for both preheater and reactor, the tube will need to be sized for the preheater and the reactor will be longer than if the tube was sized for the reactor section alone.

It is an open question whether solids will not deposit even at velocities greater than calculated critical velocities. No data have been published that validates critical velocity correlations for solids in supercritical water, and some researchers have found that deposition and plugging of tubular reactors can occur at velocities above the critical velocity. ${ }^{\mathrm{d}}$ Studies at Sandia of salt deposition in a tubular reactor showed increased deposition with increased flow rate. 22 Runs were made with $0.5 \% \mathrm{Na}_{2} \mathrm{SO}_{4}$ at flow rates of $0.6 \mathrm{~g} / \mathrm{s}$ to $1.5 \mathrm{~g} / \mathrm{s}$ in $3 / 16$ in. ID tubing. However, the maximum flow rate in these experiments, $1.5 \mathrm{~g} / \mathrm{s}$, corresponds to only about $40 \%$ of the critical velocity predicted by the Davies correlation at a temperature of $400^{\circ} \mathrm{C}^{28}$ Tests in the mid-1980s in tubular reactors by Modar revealed that neutralization salts such as $\mathrm{NaCl}, \mathrm{Na}_{2} \mathrm{SO}_{4}$, and $\mathrm{CaCl}_{2}$ are "sticky," and build up on the walls of the reactor. ${ }^{29}$ Modar ran tests with velocities as high as $50 \mathrm{ft} / \mathrm{sec}$, well above the critical velocity of deposition, and still saw deposition of neutralization salts. ${ }^{\mathbf{d}}$

Very little work has been performed to understand the chemistry of deposition. Modar has found that certain solids, such as oxides, are not "sticky" and will not lead to plugging of a tubular

d. Personal communication with Glenn Hong, October 19, 1994. 
reactor. Neutralization salts, however, are the primary concern. ${ }^{e}$ Normal melting points of several salts are shown below:

$\begin{array}{ll}\mathrm{CaCl}_{2} & 772^{\circ} \mathrm{C} \\ \mathrm{NaCl} & 801^{\circ} \mathrm{C} \\ \mathrm{Na}_{2} \mathrm{CO}_{3} & 851^{\circ} \mathrm{C} \\ \mathrm{Na}_{2} \mathrm{SO}_{4} & 884^{\circ} \mathrm{C}\end{array}$

While the above temperatures are $200-300^{\circ} \mathrm{C}$ above typical reactor temperatures, in the presence of high concentrations of water at high pressure, hydrates may form that have much lower melting points. For example, the melting point of $\mathrm{CaCl}_{2} \cdot \mathrm{H}_{2} \mathrm{O}$ is only $260^{\circ} \mathrm{C}$.

A second method that has been proposed for control of deposition in tubular reactors is redissolution of deposited salts. ${ }^{21}$ In redissolution, the waste flow is replaced by clean water and the reactor temperature is reduced in order to redissolve salts deposited on the reactor walls. Redissolution can be effective only for solids that become soluble at lower temperatures and would add both run time and additional waste water to the SCWO operation. Sandia researchers estimated that a 1.33 -in. ID, 50 gph tubular reactor would plug in 4 minutes using a $2.5 \mathrm{wt} \%$ sodium sulfate feed. ${ }^{22}$ Redissolution that is required every few minutes would significantly add to the waste water produced by the process and the run time.

A third means proposed for handling deposition in tubular reactors is through mechanical removal of solids from the reactor. Modell has patented an online cleaning system in which brushes are periodically sent through the tubular reactor. ${ }^{14}$ No data are available to determine the effectiveness of this system, apart from what is discussed in Section 4.1.

The two issues of corrosion and solids deposition throw considerable doubt upon the economic feasibility of tubular reactors for SCWO of DOE mixed waste. The required size of the reactor, an ID of approximately $1 \mathrm{in}$. and a length on the order of 500 to $1,000 \mathrm{ft}$, complicates these two issues. The long length results in a reactor with bends or in a coil configuration, increasing the likelihood of deposition and complicating techniques for solids removal and heat exchange. Likewise, the dimensions make certain coatings infeasible; the configuration makes liners hard to fabricate, install, and monitor; the length makes monitoring of corrosion difficult. For certain DOE mixed wastes that do not contain acid precursors or more than trace amounts of inorganic material, tubular reactors have promise for meeting all treatment requirements while being economic. However, this is not the case for the bulk of DOE mixed waste.

Certain design or operating features have been proposed to address the issues of corrosion or deposition in tubular reactor designs. Section 4 reviews designs of specific reactors in greater detail and any test data that would suggest the reactor's performance processing DOE waste. In general, however, these measures have either proven costly or unsuccessful.

e. Stone and Webster Corp., Assessment and Development of an Industrial Wet Oxidation System for Burning Waste and Low Grade Fuels, Final Report-Phase IIB, Pilot Demonstration of the Modar Supercritical Water Oxidation Process, Draft, January 1994. 
A final consideration in a general evaluation of tubular reactors is heat transfer requirements and temperature control. It is anticipated that to be economic, the reactor must be able to process waste with heating values in the approximate range 1,000-1,800 Btu/b or greater, and also that the reactor residence time must be about 30 seconds (see Appendices A and B). To achieve the latter requirement, reaction temperatures must be in the $550-600^{\circ} \mathrm{C}$ range, where reaction rates are fast. If reaction rates are fast, the rate of heat release from the reaction is also fast. This heat is typically used in tubular reactors to raise the feed mixture from a "preheat" temperature to the "reaction" temperature. For dilute wastes, with heating values less than about $300 \mathrm{Btu} / \mathrm{lb}$, the heat released by the reaction is equal to that needed to raise the fluid temperature from the preheat temperature to the reaction temperature.

However, for more concentrated wastes, heat must be removed from the reactor or the temperature will rise above tube wall temperature limits. Tubular designs have two major limitations in removal of reaction heat. The heat released along the length of the reactor falls off exponentially, which for a constant diameter tube, would require an exponentially changing product of the heat transfer coefficient (U) times the temperature difference $(\Delta T)$ between reactor fluid and coolant. For a given reactor design, one feedstock would result in hot spots while another would have inadequate conversion due to quenching the reaction through overcooling. The second problem is that at temperatures above about $550^{\circ} \mathrm{C}$, reaction heat is released at a rate faster than it can be removed.

To illustrate, consider the oxidation of methanol in water, at a $16.6 \%$ methanol concentration (equivalent to $1,500 \mathrm{Btu} / \mathrm{b}$ ), a reaction temperature of $520^{\circ} \mathrm{C}$ and $20 \%$ excess oxygen. Table 3 shows the conversion and heat duty that must be removed from the reactor in different sections of the reactor.

If the reactor is 1.5 -in. schedule 160 pipe, the above heat duty would require an average $\mathrm{U} \Delta \mathrm{T}$ product of $40,000 \mathrm{Btu} / \mathrm{ft}^{2}-\mathrm{hr}$ in the first section, $6,500 \mathrm{Btu} / \mathrm{ft}^{2}-\mathrm{hr}$ in the second section, and only $1,000 \mathrm{Btu} / \mathrm{ft}^{2}-\mathrm{hr}$ in the third section. These values illustrate the difficulty of maintaining a constant temperature in the reactor, removing heat at very high rates in the first part of the reactor without quenching the reaction in the latter sections. They also illustrate the narrow temperature range between a lower limit where residence time becomes excessive and an upper limit where heat release becomes excessive. If the preheat temperature is below about $425^{\circ} \mathrm{C}$, a residence times of minutes would be required to reach the reaction temperature. As seen in Table 3 , a reaction temperature of $520^{\circ} \mathrm{C}$ requires approximately 50 seconds residence time to reach a destruction efficiency of $99.99 \%$. Table 4 shows the required heat removal for the SCWO of methanol for a reaction temperature of $550^{\circ} \mathrm{C}$ and preheat temperature of $450^{\circ} \mathrm{C}$.

With the heat removal rates as high and as variable with reactor length as shown in Table 4, temperature control would be extremely difficult to achieve, and either hot spots or reaction quenching would likely result. 
Table 3. Supercritical water oxidation of methanol at $520^{\circ} \mathrm{C}$.

\begin{tabular}{ccccc}
\hline Section & $\begin{array}{c}\text { Residence time } \\
(\text { seconds) }\end{array}$ & $\begin{array}{c}\text { Conversion } \\
(\%)\end{array}$ & $\begin{array}{c}\text { Conversion } \\
\text { per section } \\
(\%)\end{array}$ & $\begin{array}{c}\text { Heat duty per section } \\
(\text { Btu/hr })^{b}\end{array}$ \\
\hline 1 & 10 & 84.6 & 84.6 & $1,300,000$ \\
2 & 20 & 97.6 & 13 & 210,000 \\
3 & 30 & 99.6 & 2 & 32,000 \\
4 & 40 & 99.94 & 0.34 & 5,500 \\
5 & 50 & 99.992 & 0.05 & 800 \\
6 & 60 & 99.999 & 0.007 & 100
\end{tabular}

a. An additional 17 seconds would be required to reach reaction temperature from a preheat temperature of $450^{\circ} \mathrm{C}$.

b. Based on $827 \mathrm{lb} / \mathrm{hr} 16.6 \mathrm{wt} \%$ methanol (500 gpd $100 \%$ methanol).

Table 4. Supercritical water oxidation of methanol at $550^{\circ} \mathrm{C}$.

\begin{tabular}{ccccc}
\hline Section & $\begin{array}{c}\text { Residence time } \\
(\text { seconds })\end{array}$ & $\begin{array}{c}\text { Conversion } \\
(\%)\end{array}$ & $\begin{array}{c}\text { Heat duty per section } \\
\left(\mathrm{Btu} / \mathrm{hr} \mathbf{r}^{\mathrm{a}}\right)\end{array}$ & $\begin{array}{c}\mathrm{U} \Delta \mathrm{T} \\
\left(\mathrm{Btu} / \mathrm{hr}-\mathrm{ft}^{2}\right)\end{array}$ \\
\hline 1 & 17 & 8.5 & 0 & 0 \\
2 & 17.24 & 40 & 500,000 & 690,000 \\
3 & 17.47 & 60 & 320,000 & 460,000 \\
4 & 17.86 & 80 & 320,000 & 380,000 \\
5 & 18.25 & 90 & 160,000 & 190,000 \\
6 & 19.5 & 99 & 145,000 & 52,000 \\
7 & 20.8 & 99.9 & 15,000 & 5,000 \\
8 & 22.1 & 99.99 & 1,500 & 500 \\
\hline
\end{tabular}




\section{EVALUATION OF SPECIFIC REACTOR DESIGNS}

Tubular reactor designs have been patented by Modell ${ }^{14}$ and by Li and Gloyna. ${ }^{13}$ Other patents that cover SCWO processes discuss or describe tubular reactors, including patents issued to Dickinson, ${ }^{12}$ Welch and Slegwarth, ${ }^{11}$ Rofer and other researchers at Los Alamos, ${ }^{27}$ and Sawicki, Casas, Huang, Kililea, and Hong. ${ }^{23}$

\subsection{Modec Constant Diameter Tubular Reactor}

The major unique feature of the Modell reactor design is that the internal diameter is "substantially constant."14 The reactor includes preheating and effluent cooling sections that are part of the constant diameter reactor. Bench-scale testing has been performed using the Modell reactor for one of the DOE simulated wastes, TRIMOSOL, ${ }^{15,30}$ surrogates for DOE mixed waste stored in tanks at Hanford, ${ }^{18}$ and simulated industrial wastes. ${ }^{18,31}$

The goal of the tests with TRIM@SOL was to evaluate the ability of the Modell SCWO system to treat a highly chlorinated waste with added solids. Tests were planned in order to assess corrosion and deposition in the reactor from treatment of this waste. Four series of tests were performed. The first series used an organic alcohol to calibrate the system and establish baseline conditions. In the second series, optimum conditions for processing the TRIMOSOL waste were determined, including the maximum concentration of TRIMOSOL that could be processed. Based on concentrations of nickel and chromium in the effluent that indicate corrosion, the maximum TRIM@SOL concentration was limited to 3.75\%. Tests 3 and 4 were run with a TRIM $\odot$ SOL concentration of $3.75 \%$, and with concentrations of zinc, lead, and cerium of 77,127 , and $149 \mathrm{ppm}$ respectively, to evaluate deposition in the reactor. Inconel 625 witness wires were installed in the reactor in Test 4 to measure corrosion rates.

Figures 6 and 7 show corrosion rates as determined from measurements of witness wire diameter. Figure 6 is based on witness wires exposed for 20 hours, and Figure 7 for 40 hours. The figures show relatively low corrosion rates in the reaction section of the reactor, but high rates in the preheater and the cool-down section. Corrosion rates greater than 1,000 mils per year are seen in the preheater at surface temperatures as low as $230^{\circ} \mathrm{C}$. Metallographic analysis of the witness wires led to the conclusion that both general and intergranular attack occurred throughout the reactor, although intergranular attack was inconsistent in its location. Based on the corrosion seen on the witness wires, it was concluded that Inconel 625 is not suitable for the tested environment.

Deposits seen on the witness wires seemed to affect corrosion rates. Apparently, corrosion would occur in a specific area, and then slow or stop as the layers of scale formed on the section of wire. The scale would then spall off, and corrosion began again.

Mass balances of Tests 3 and 4 provide estimates of deposition of solids in the reactor. Salts of zinc, cerium, and lead were added to the feed in these tests; in addition TRIM๑SOL contains significant levels of sodium and potassium. The amount of sodium and potassium recovered in all liquid and solid effluents amounted to less than $12 \%$ of the amount in the feed. The amount of zinc and cerium in the solids and liquid effluent amounted to $20-30 \mathrm{wt} \%$ of the amount added to 
MODEC Bench Scale Test Profile Test $4-20 \mathrm{hrs}$

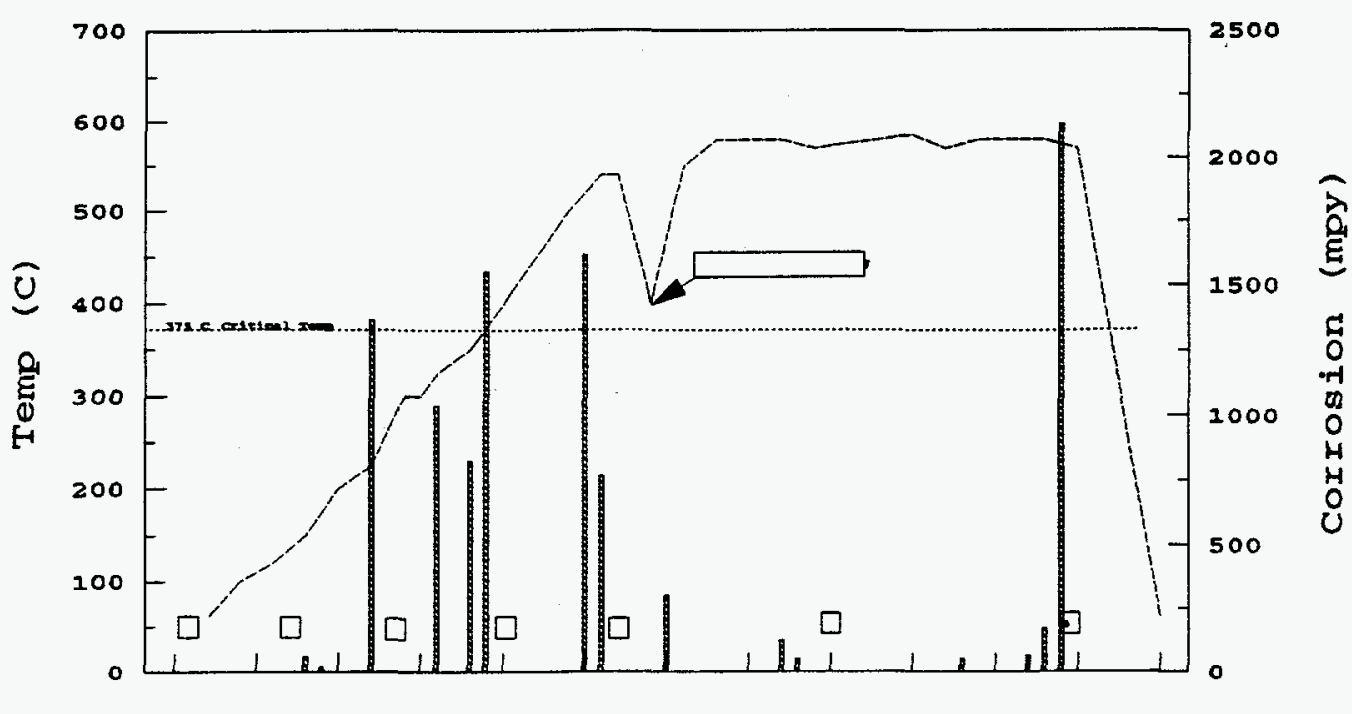

Nondimensional length

Power \& oround connectlone $\square$ M1ls per year Temperacure ㄴ.

Figure 6. Corrosion rate for 20-hour witness wire.

MODEC Bench Scale Test Profile Test 4 - 40 hrs.

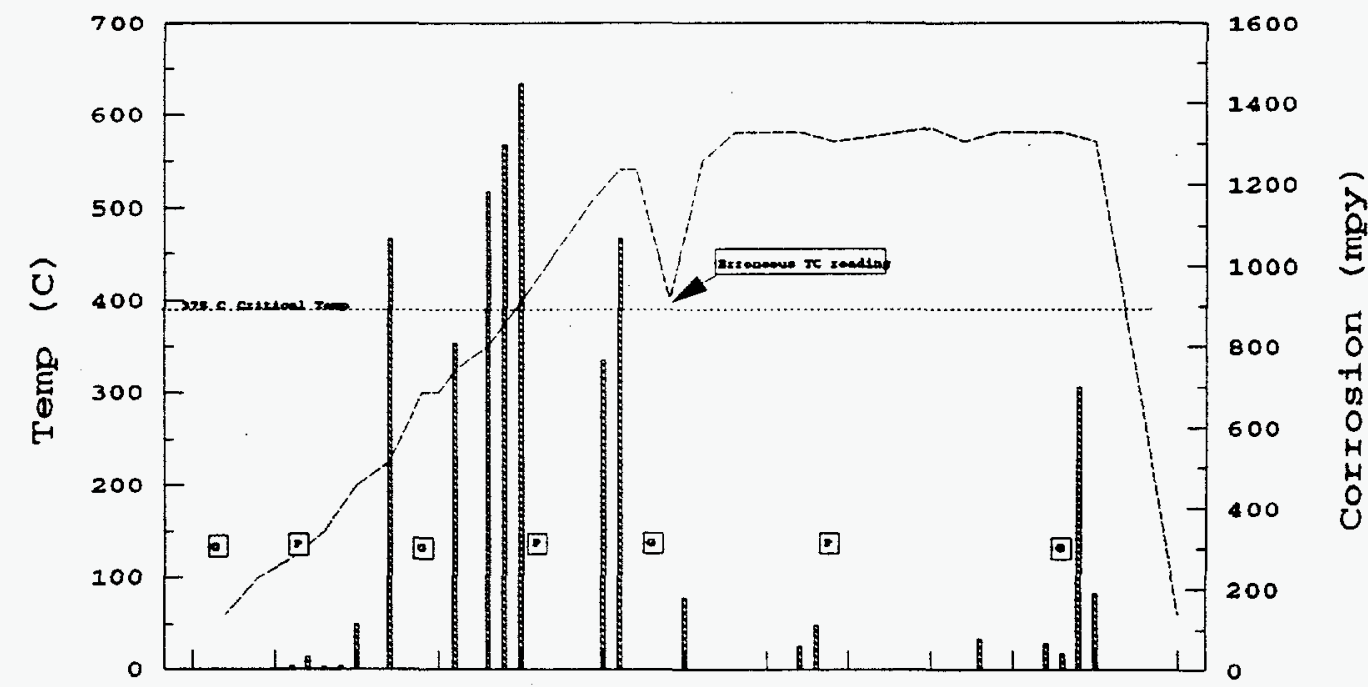

Power Exound connectione $\square$

Nondimensional length

Mils per year Temperature

1

Figure 7. Corrosion rate for 40 -hour witness wire. 
the feed for Tests 3 and 4, while the amount of lead in the effluents was 40-50\%. For Test 4, the reactor was brushed to remove deposits, and the solids removed are included in the above recovery percentages. Thus, it appears that over $90 \%$ of the sodium and potassium salts that entered the reactor were deposited and only a few percent could be removed with brushing. Higher percentages of the heavy metals were recovered and removal techniques were more effective. Yet $50 \%$ or more of these metals were unaccounted for in effluent streams. The velocity in the reactor for the TRIM@SOL tests was below the calculated critical velocity for deposition, approximately $26 \%$ of the critical velocity based on sodium chloride, or $13 \%$ of the critical velocity based on lead oxide.

Other simulated DOE mixed wastes were tested in a Modell tubular bench-scale reactor at Sandia National Laboratories. ${ }^{18}$ As with the TRIM बSOL tests, the reactor was constructed of Inconel 625. A simulated Rocky Flats waste was tested that contained 2\% methanol, 98\% water, and about $1,300 \mathrm{ppm}$ of mostly chlorinated hydrocarbons. At this level of chlorine, no obvious corrosion was seen. However, corrosion was seen when testing the Hanford tank waste and Hanford tank waste matrices. The Hanford tank waste contained nitric acid, sodium nitrate, sodium carbonate, the sodium salt of ethylene diamine tetra-acetic acid (EDTA), ppm levels of 14 other inorganic and organic compounds, and was neutralized with sodium hydroxide to a $\mathrm{pH}$ of 7-9.5. Hanford matrices were single compounds meant to determine the performance of the system with the major components of neutralized Hanford tank waste, and included ammonium nitrate, sodium nitrate, and potassium nitrate. Waste concentration for the Hanford waste and matrices tests was in the range $1-5 \%$, most often $2 \%$.

Sandia researchers were not able to identify an acceptable neutralizing or buffering agent that would give corrosion-free processing in the Inconel 625 reactor. ${ }^{18}$ Runs were made with neutralization or buffering agents ammonium nitrate, potassium dihydrogen orthophosphate, and sodium hydroxide. Witness wires of Inconel 625, Hastelloy C-276, and titanium were used in some runs to gain additional corrosion data. With the Hanford tank waste, extensive deposition of phosphate was seen on an Inconel 625 witness wire in the preheat section as well as iron species. In the first $20 \%$ of the reaction zone, extensive precipitation of manganese, zinc, and iron was seen. In the remainder of the reactor and the first half of the cooldown section, attack on the wire was seen with selective dissolution of chromium.

Another run with an Inconel witness wire was made with a feed of $2 \%$ sodium nitrate to see the effect of not having the deposition species. Greater dissolution of chromium is seen in the highest temperature region of the reactor than was seen using the simulated Hanford tank waste formulation. At the point halfway into the cooldown section, there was a very sharp zone of deposition of iron and chromium. With a Hastelloy C-276 witness wire and a feed of $2 \%$ sodium nitrate, corrosion was seen in the first half of the reaction section, with decreases in the nearsurface concentrations of $\mathrm{Mo}, \mathrm{Cr}$, and $\mathrm{W}$ of up to 35,60 , and $70 \mathrm{wt} \%$, respectively.

As in the TRIM SOL tests, low recoveries of surrogate radionuclides were seen in the Sandia tests. Recovery of lanthanum, neodymium, and cerium were $47 \%, 30 \%$ and $7 \%$ respectively. Areas of deposition were observed not only in the high temperature reaction region, but also the preheat and cooldown sections. It should be noted that these tests were also run with velocities well below the calculated critical velocity for maintaining solids in suspension. 
Modell's bench-scale reactor has also been used to test pulp mill sludges, ${ }^{31}$ sewage sludge, ${ }^{14}$ and surrogates for chemical warfare agents. ${ }^{14}$ In these tests, as well as the TRIMOSOL tests and the tests of simulated DOE and industrial waste at Sandia, high organic destruction efficiencies have been seen. The accumulating data on destruction efficiency for a variety of wastes lead to high confidence that the Modell reactor would achieve the destruction of organics in DOE mixed waste to whatever level was required. The two major issues are corrosion and deposition. DOE mixed wastes could be diluted with high volumes of water to reduce both corrosion and deposition. However, for wastes such as TRIMOSOL, the dilution would need to be on the order of 300 to 1 . The capital and operating costs associated with such a unit would likely not be economically viable compared to other technologies that process waste with little or no dilution. And even with dilution there may still be operating problems because of corrosion and deposition.

In the Modec design, the functions of preheating the feeds, reacting organics and cooling effluents are performed in a single tube with appropriate heat exchange on different sections according to the requirements of the waste to be treated. Typically all feeds-waste, water, and oxidant-are combined and heated together, although addition of oxygen in the reaction section is mentioned in the patent as an alternative scheme. With the organic and oxidant heated together in the preheater, the oxidation reaction will begin in the temperature range of $250-350^{\circ} \mathrm{C}$. Reaction rates will vary with individual organic compounds and conversions for the more reactive species may reach a few percent. Even very low reaction rates of halogenated hydrocarbons in the preheater will result in very acidic and corrosive fluids, along with corrosion products that may form deposits.

Decomposition of chlorinated hydrocarbons at subcritical temperatures was confirmed by studies at the Chemical Science and Technology Laboratory at the National Institute of Standards and Technology. ${ }^{20}$ Raman spectroscopy showed that trichloroethylene decomposed to dichloroethylene at $200^{\circ} \mathrm{C}$, and at $300^{\circ} \mathrm{C}$ decomposition of methylene chloride amounted to $60-90 \% .^{20}$

Integrating the reactor with the effluent cooler promotes corrosion in the cooler, if acid gases are present in the reactor effluent. A single diameter tubular preheater/reactor/cooler can also lead to deposition of solids in the preheater or overdesign of the reactor. If the diameter is set by the critical velocity in the reaction section, then the velocity in the preheater will be less than the critical velocity, increasing the likelihood of deposition. On the other hand, if the diameter is set by the critical velocity in the preheater, the length of the reactor may be several times longer than the length based on design for critical velocity in the reactor.

\subsection{Dickinson Tubular Reactor Designs}

The various tubular reactor configurations shown in Figure 1 differ from the Modec reactor primarily in heat transfer methods and locations and methods that feeds are mixed. In the Dickinson designs, ${ }^{12}$ air and fuel slurry are preheated separately and mixed in the reactor via nozzles and venturis. Cool recycle fluid is also mixed with the reaction mixture at one or more intermediate points in the reactor to avoid excessive temperatures. The issues of corrosion and solids deposition for tubular reactors in general apply to the Dickinson design. In addition, temperature control through recycle would likely be problematic. 
The Dickinson reactor was designed for solid fuels; the DOE mixed wastes contain waste types and constituents beyond the scope mentioned in Dickinson patents, including halogenated organic liquids, tributyl phosphate, radionuclides, numerous inorganic species, and a wide range of combustible wastes. These wastes set requirements on heat transfer, corrosion, and solids transport that may not be met by the Dickinson reactor.

U.S. patent $4,380,960$ implies that the process is economic only for concentrations of waste in the range of approximately $9-75 \%$. While processing high concentrations of waste is desirable from the standpoint of economics, concentrations in excess of about $20 \%$ require either a high rate of heat removal from the reactor or high rates of cooling water injected into the reacting mixture. The Dickinson design utilizes the latter approach. However, the wide range of waste compositions of DOE wastes give rise to kinetic differences that in turn would result in varying cooling water requirements from waste to waste, both in the amount and location of injection. Matching heat transfer requirements to kinetics would likely be impossible. To illustrate, consider processing a feed of $16.6 \%$ methanol. Based on the kinetics of methanol oxidation in supercritical water given in Reference 32 , at $500^{\circ} \mathrm{C}, 7.5 \%$ of the feed methanol would be converted in 2 seconds, and the temperature would be raised to $600^{\circ} \mathrm{C}$. Within another 0.0014 seconds, or approximately $0.2 \mathrm{in}$. of reactor length, the temperature of the reacting fluid would have reached $700^{\circ} \mathrm{C}$. Thus, to avoid hot spots in the reactor, multiple injection locations per inch would be needed as well as very exact characterization of the feed waste. If the reactor was operated at a lower temperature, say $450^{\circ} \mathrm{C}$, to allow a broader range of temperature fluctuation, the kinetics would require that the reactor length be increased by a factor of 80 .

The Dickinson process uses an alkali to neutralize acid gases in the reactor. While in situ neutralization may be acceptable for the halogenated DOE wastes to avoid corrosion, no test data are available. With in situ neutralization, solids deposition becomes a major concern. The Dickinson patents contain no specific methods for maintaining solids in suspension, nor is any test data presented demonstrating the proposed reactors even for coal slurries.

\subsection{Welch and Slegwarth Annular Reactor}

Welch and Slegwarth ${ }^{11}$ describe an annular or bayonet-type SCWO reactor to treat low concentration organic wastes in water, typically $1 \mathrm{wt} \%$. This concentration is about 10 times lower than what is desired for treatment of DOE wastes, and is likely economically infeasible (see Appendix A). To process 500 gpd of organic waste, a 50,000 gpd SCWO unit would be required. Based on sizing the reactor to maintain a velocity to keep particles with specific gravities less than 5.7 in suspension, the reactor would consist of a 3.5 -in. schedule 80 outer pipe and 2.0 -in. schedule 5 inner pipe. The length of the reaction section would be about 1,200 ft. Annular type reactors, or any tubular reactor that uses feed/effluent exchange, have a limitation because of the heat capacity spike of water near its critical temperature. The feed heat curve in the critical region is similar to a material undergoing a phase change, with a large change in duty required over a small change of temperature. So in the region of the feed/effluent exchanger near the critical temperature, the temperature difference between feed and effluent will be very small.

Besides economics, another major weakness of the Welch and Slegwarth design is the likelihood for solids deposition. Like the other designs, in situ neutralization could be used to minimize corrosion, yet deposition of sticky solids would be expected. Apart from one example 
given in the patent of a feed that contained neither solids or acid precursors, no test data for this reactor are available.

\subsection{Li and Gloyna Reactor}

Like the Modec reactor, the Li/Gloyna reactor consists of a preheater, reactor, and effluent cooler integrated in a single piece of equipment. A sketch, taken from Reference 13, is shown in Figure 3. Like the Welch and Slegwarth design, feeds are heated in an annulus and then react in the inner tube. And like the Dickinson design, a portion of the reactor effluent is recycled, although for a different purpose. The unique features of the Li/Gloyna reactor consist of its particular combination of heat transfer methods and the use of sintered separators internal to the reactor.

The novelties of the $\mathrm{Li} / \mathrm{Gloyna}$ reactor are for the purpose of avoiding scale formation in the preheater due to reactions, and scale in the reactor due to inadequate mixing and deposition of precipitated particles. Feed organic is introduced into the reactor cold, and heated quickly to reaction temperature by mixing with hot, recycled water. The oxidant is introduced into the reactor separately. An internal filter reduces the amount of solids that enter the inner tube, where most of the reaction takes place.

While this reactor has some unique features, it does not appear to meet the requirements for the full range of DOE wastes or be flexible to handle a range of waste compositions. To achieve a stable temperature profile in the reactor, the heat generated by reaction in the inner tube must equal the heat transferred through the tube wall and gained by the feed/recycle/oxidant mixture. The heat of reaction, governed by kinetics, varies exponentially with temperature. The higher the temperature, the faster the reaction, the higher the conversion, and the higher the rate of heat released by reaction. At temperatures around $500^{\circ} \mathrm{C}$, conversions reach $99 \%$ in seconds, and at temperatures in the $550-600^{\circ} \mathrm{C}$ range, in fractions of a second. The amount of heat released by the reaction at these temperatures cannot be absorbed by the feed mixture because of the relationship of sensible heat to temperature, and thus, hot spots and a changing temperature profile in the reactor would result. At lower temperatures, in the $400-450^{\circ} \mathrm{C}$ range, reaction rates are lower and temperatures could more easily be controlled, but a residence time on the order of an hour would likely be required. To achieve a residence time of one hour in a 1-in. ID tube would require a length of $59,000 \mathrm{ft}$. The size of the reactor would make the process economically infeasible. Difficult as the design would be for a single feedstock, for a range of feed compositions, different kinetics will shift temperature profiles and make control of temperature, and hence conversion, all the more difficult.

$\mathrm{Li}$ and Gloyna make no mention of treating wastes with high levels of halogenated organics; corrosion is expected to be a problem with the design. If in situ neutralization is used to control corrosion, the resulting sticky salts will deposit and may plug the filter or reactor. Other solids may also cause plugging in the filter, resulting in high maintenance. 


\subsection{Other Tubular Reactor Designs}

Bench-scale and in a few cases pilot-scale testing have been performed with other tubular reactors by Sandia, Los Alamos, the University of Texas, and Modar. Much of the testing was done to obtain kinetic or destruction efficiency data, with test feeds that in most cases contained neither acid precursors or inorganic solids.

Los Alamos researchers have patented a process for SCWO that utilizes "tubing, arranged in a coil" for the reactor. ${ }^{27}$ No further details of the reactor are specified. The process uses no separate oxidant, hence it can only apply to wastes such as nitrates or perchlorates that are themselves oxidizers. With the exception of Hanford tank waste, only a very small percentage of DOE mixed waste would fall in this category. A neutralization agent is added to avoid formation of chlorine gas, and the pressure is set to maintain the resulting salt in solution. In the example cited of treatment of ammonium perchlorate neutralized with sodium hydroxide, a pressure of 5,500 psig was used. For the same example, which utilized a reactor of Hastelloy-276, and in spite of neutralization, evidence of corrosion was seen by the levels of chromium of 59-130 ppm, nickel of $26-39 \mathrm{ppm}$, and molybdenum of $10-54 \mathrm{ppm}$ in the effluent. ${ }^{33}$

A tubular reactor was also found to be adequate for the destruction of a waste water containing aromatic nitrates, ${ }^{34}$ and a patent was issued for the process. ${ }^{23}$ The pilot-scale reactor consisted of a tube 0.215 in. ID by $530 \mathrm{ft}$ long, coiled around a 12-in. diameter pipe. In separate tests, it was found that the reactor plugged within 30 seconds whenever the temperature exceeded $370^{\circ} \mathrm{C}$, due to salts from sodium present in the waste. Thus, to avoid plugging the temperature was kept below $370^{\circ} \mathrm{C}$. For DOE wastes, temperatures this low would require residence times of hours to achieve adequate destruction efficiencies. Such long residence times would make the reactor economically infeasible due to its size. 


\section{CONCLUSIONS}

Minimal pilot-scale data are available to use to evaluate tubular reactors. However, benchscale data raise doubt about their performance treating most DOE mixed wastes because of corrosion and deposition that would lead to operational problems and high costs.

At present there does not appear to be an economic means of controlling corrosion in tubular reactors for wastes with high levels of acid precursors. The high chloride content of some DOE wastes makes feed dilution economically infeasible as a means of corrosion control. Materials such as Inconel 625 and Hastelloy C-276 have been tested and are not recommended for high chloride content wastes, and no other single material or set of materials have been proposed for tubular reactors treating wastes that produce more than ppm levels of hydrochloric, hydrofluoric, and sulfuric acid. In situ neutralization would likely result in plugging tubular reactors and may not sufficiently reduce corrosion rates.

At present there does not appear to be a tubular reactor design that would avoid deposition of salts, radionuclides and other inorganic materials. Redissolution of deposited material would only be successful for soluble deposits, and would considerably increase the total effluent volume. A very small diameter tube, approximately 1 -in. ID, would be required to achieve a velocity greater than the critical velocity for settling of solid particles. With such a diameter, the reactor length would need to be on the order of 500-1,000 ft long to achieve adequate destruction efficiency. Critical velocity correlations have not been verified at supercritical water conditions. And some test data have shown that some solids such as neutralization salts will deposit at fluid velocities in excess of the critical. Mechanical techniques of solids removal from tubular reactors have not been demonstrated.

Bench-scale test data for the single diameter tubular reactor have consistently shown evidence of corrosion when treating waste with acid precursors and deposition of inorganic species.

Problems of temperature control or inadequate heat transfer are expected for tubular designs, for feeds with $10-15 \%$ organics. The high rate of heat released from oxidation reactions cannot by balanced by preheat of feed streams in annular designs, and would require complicated designs if coolant fluids were used. Heat control through dilution is unworkable for a wide range of feedstock compositions that will have different kinetics. Because of heat transfer limitations, annular reactors cannot process waste at the organic concentrations required for treatment of DOE waste.

A previous study ${ }^{10}$ rated both vessel reactor designs and porous wall reactors as better candidates for SCWO of DOE mixed waste than tubular designs. Continued bench-scale and pilot-scale testing of these designs should be pursued in preference to tubular reactors. If continued, testing of tubular reactors should focus on demonstrating proposed concepts of corrosion and deposition control such as in situ neutralization, high velocities and brushing techniques, and using wastes with levels of acid precursors and inorganics representative of DOE mixed wastes. In addition, methods of control of reaction temperature need to be developed and demonstrated for waste with high concentrations of organics. Research should be continued and 
expanded to better understand the chemistry of both corrosion at SCWO conditions and deposition. 


\section{REFERENCES}

1. J. W. Tester, H. R. Holgate, F. J. Armellini, P. A. Weber, W. R. Killilea, G. T. Hong, H. E. Barner, "Supercritical Water Oxidation Technology: A Review of Process Development and Fundamental Research," ACS Symposium Series, Vol. 513, 1993, pp. 35-76.

2. E. F. Gloyna and L. Li, "Supercritical Water Oxidation: An Engineering Update," Waste Management, 13, 1993, pp. 379-394.

3. R. C. Moore and J. M. Simonson, A Review of Supercritical Water Oxidation Research and Technology, ORNL/CF-93/39, February 1993.

4. C. M. Barnes, R. W. Marshall, Jr., R. E. Mizia, J. S. Herring, E. S. Peterson, Identification of Technical Constraints for Treatment of DOE Mixed Waste by Supercritical Water Oxidation, EGG-WTD-10768, October 1993.

5. U.S. Environmental Protection Agency, Engineering Bulletin on Supercritical Water Oxidation, EPA/540/S-92/006, September 1992.

6. H. E. Barner, C. Y. Huang, T. Johnson, G. Jacobs, M. A. Martch, "Supercritical Water Oxidation: An Emerging Technology," Journal of Hazardous Materials, 31, 1992, pp. 1-17.

7. R. W. Shaw, T. B. Brill, A. A. Clifford, C. A. Eckert, E. U. Franck, "Supercritical Water - A Medium for Chemistry," Chemical and Engineering News, December 23, 1991, pp. 26-39.

8. M. Modell, "Supercritical Water Oxidation," Standard Handbook of Hazardous Waste Treatment and Disposal, H. F. Freeman (ed.), McGraw-Hill Book Co., 1988.

9. C. M. Barnes, Mixed Waste Survey for the Supercritical Water Oxidation Program EGG-WTD-10984, November 1993.

10. C. M. Barnes, "Chemical Reactor Design for Supercritical Water Oxidation of U.S. DOE Waste," First International Conference on Advanced Oxidation Technologies for Water and Air Remediation, London, Ontario, Canada, June 25-30, 1994.

11. J. F. Welch and J. D. Slegwarth, Method for the Processing of Organic Compounds, U.S. Patent 4,861,497, August 29, 1989.

12. N. L. Dickinson, Pollution-Free Low Temperature Slumy Combustion Process Utilizing the Supercritical State, U.S. Patent 4,380,960, April 26, 1983.

13. L. Li and E. F. Gloyna, High Temperature Wet Oxidation Using Sintered Separators, International Patent Application PCT/US92/06459, February 18, 1993. 
14. M. Modell, Supercritical Water Oxidation Process of Organics with Inorganics, U.S. Patent $5,252,224$, October 12, 1993.

15. C. Shapiro, K. Garcia, J. Beller, "Treatment of a Simulated Mixed Waste with Supercritical Water Oxidation," Proceedings of the Second International Symposium on Mixed Waste, Baltimore, Maryland, August 17-20, 1993, pp. 10.3.1-10.3.16.

16. A. J. Thomas III and E. F. Gloyna, Corrosion Behavior of High-Grade Alloys in Supercritical Water Oxidation of Sludges, Center for Research in Water Resources Bureau of Engineering Research, University of Texas at Austin Technical Report CRWR 229, February 1991.

17. R. M. Latanision and R. W. Shaw, Corrosion in Supercritical Water Oxidation Systems: Workshop Summary, MIT-EL 93-006, September 1993.

18. T. T. Bramlette, B. E. Mills, K. R. Hencken, M. E. Brynildson, S. C. Johnson, J. M. Hruby, H. C. Feemster, B. C. Odegard, M. Modell, Destruction of DOE/DP Surrogate Wastes with Supercritical Water Oxidation Technology, SAND90-8229, November 1990.

19. D. M. Harradine, S. J. Buelow, P. C. Dell'Orco, R. B. Dyer, B. R. Foy, J. M. Robinson, J. A. Sanchez, T. Spontarelli, J. D. Wander, "Oxidation Chemistry of Energetic Materials in Supercritical Water," Hazardous Waste and Hazardous Materials, 10, 1993, pp. 233-246.

20. R. E. Kirts, Destruction of Navy Hazardous Waste by Supercritical Water Oxidation, TR-2025-ENV, August 1994.

21. C. A. LaJeunesse, J. P. Chan, T. N. Raber, D. C. Macmillan, S. F. Rice, K. L. Tschritter, Supercritical Water Oxidation of Colored Smoke, Dye, and Pyrotechnic Compositions, Final Report: Pilot Plant Conceptual Design, SAND94-8202, November 1993.

22. C. A. LaJeunesse, S. F. Rice, R. G. Hanush, J. D Aiken, Salt Deposition Studies in a Supercritical Water Oxidation Reactor (Interim Report), SAND94-8201, October 1993,

23. J. E. Sawicki, B. Casas, C. Y. Huang, W. R. Killilea, G. T. Hong, "Wet Oxidation of Aqueous Streams," U.S. Patent 5,250,193, October 5, 1993.

24. J. M. Robinson, B. R. Foy, P. C. Dell'Orco, G. Anderson, F. Archuleta, J. Atencio, D. Breshears, R. Brewer, H. Eaton, R. McFarland, R. McInroy, T. Reynolds, M. Sedillo, E. Wilmanns, S. J. Buelow, "Destruction of Nitrates, Organics, and Ferrocyanides by Hydrothermal Processing," Proceedings of the Symposium on Waste Management at Tucson, Arizona, February 28-March 4, 1993, pp. 709-716.

25. C. F. Matthews and E. F. Gloyna, Corrosion Behavior of Three High-Grade Alloys in Supercritical Water Oxidation Environments, Center for Research in Water Resources Bureau of Engineering Research, University of Texas at Austin Technical Report CRWR 234, June 1992. 
26. R. T. Loda, "DARPA Supercritical Fluid Related Tasks," Proceedings, Workshop on Federal Programs Involving Supercritical Water Oxidation, Gaithersburg, Maryland, July 6-7, 1992, pp. 255-286.

27. C. K. Rofer, S. J. Buelow, R. B. Dyer, J. D. Wander, "Conversion of Hazardous Materials Using Supercritical Water Oxidation," U.S. Patent 5,133,877, July 28, 1992.

28. J. T. Davies, "Calculation of Critical Velocities to Maintain Solids in Suspension in Horizontal Pipes," Chemical Engineering Science, 42, 1987, pp. 1667-1670.

29. J. A. Bettinger, E. D. Ferland, W. Killilea, "Demonstration of the Modar Supercritical Water Oxidation Process," Waste Management Meeting, Tucson, Arizona, February 28-March 4, 1994.

30. M. Modell, Assessment and Development of an Industrial Wet Oxidation System for Burning Waste and Low-Grade Fuels, Final Report, DOE/ID/12915/FIN, December 1993

31. M. Modell, Treatment of Pulp Mill Sludges by SCWO: Final Report, DOE/CE/40914-T1, July 1990.

32. J. W. Tester, P. A. Webley, H. R. Holgate, "Revised Global Kinetic Measurements of Methanol Oxidation in Supercritical Water," Industrial and Engineering Chemistry, Research, 32, 1993, pp. 236-239.

33. S. J. Buelow, R. B. Dyer, C. K. Rofer, J. H. Atencio, J. D. Wander, Destruction of Propellant Components in Supercritical Water, LA-UR-90-1338, 1990.

34. J. E. Sawicki and B. Casas, "Wet Oxidation System - Process Concept to Design," Environmental Progress, 12, November 1993, pp. 275-283. 


\section{Appendix A}

Estimate of Waste Concentration for an Economic Supercritical Water Oxidation Plant 



\section{Appendix A}

\section{Estimate of Waste Concentration for an Economic Supercritical Water Oxidation Plant}

In 1989, the U.S. Department of Energy (DOE) set a 30-year goal to clean up and restore the environment at its nuclear sites. ${ }^{\mathrm{A}-1}$ One of the objectives set to achieve this goal was to treat mixed waste with state-of-the-art, cost-effective technology such that no unacceptable risk to the environment, public health, and worker safety remained and to achieve regulatory compliance. Many technologies, including supercritical water oxidation, are being evaluated, developed, and demonstrated toward the goal of treatment of the DOE's stored mixed waste. Technologies under development must thus be not only technically viable, but economic competitive if they are to succeed in treatment of actual DOE mixed waste.

DOE mixed wastes include organic liquids, aqueous liquids and slurries, organic and inorganic sludges, solid combustible wastes, heterogeneous debris, and other waste categories. Each treatment technology is applicable to a set of waste types and forms, and the relative economics depend upon this set. Supercritical water oxidation is most applicable to aqueous wastes with organic contaminants. Depending on the organic content, many of these wastes can be processed as they exist. The amount of DOE mixed wastes that fit into this category, aqueous liquid with organics, is very small compared to organic liquids and combustible solids. Processing organic liquids or solids by SCWO requires dilution of the waste with water. The economics of supercritical water oxidation are highly dependent on the dilution factor because it determines the plant throughput rate.

Table A-1 shows estimated capital and operating costs for various dilution ratios of a hypothetical $100 \%$-organic waste compared to a baseline plant designed for $10 \%$ organic.

The major concern now is the relative cost of SCWO compared to competitive technologies. If a baseline SCWO unit, which dilutes waste to $10 \%$ organic, has capital and operating costs comparable to a competing technology, then higher dilution factors would make SCWO uneconomical.

Table A-1. Estimate relative costs for SCWO unit versus dilution.

\begin{tabular}{ccccc}
\hline Dilution factor & $\begin{array}{c}\text { Weight } \% \\
\text { organic }\end{array}$ & $\begin{array}{c}\text { Relative } \\
\text { throughput }\end{array}$ & $\begin{array}{c}\text { Relative capital } \\
\text { cost }\end{array}$ & $\begin{array}{c}\text { Relative operating } \\
\text { costs }\end{array}$ \\
\hline $9: 1$ & 10 & 1.0 & 1.0 & 1.0 \\
$19: 1$ & 5 & 2.0 & 1.6 & 1.8 \\
$39: 1$ & 2.5 & 4.0 & 2.6 & 3.3 \\
$99: 1$ & 1 & 10.0 & 5.0 & 7.5 \\
$300: 1$ & 0.33 & 30.0 & 11 & 20 \\
\hline
\end{tabular}


The state of development of SCWO and many competing technologies limits the accuracy of economic comparisons. However, two studies have compared costs for SCWO and alternative technologies.

Kidman and Tsuji made a preliminary cost comparison of supercritical water oxidation, several ultraviolet light-ozone or light-hydrogen peroxide processes, and electron beam technology. ${ }^{\mathrm{A}-2}$ They also included a comparison of these processes to costs of incineration and biological treatment. Their cost estimate for supercritical water oxidation was based on the Modec system, treating a dewatered pulp mill sludge containing $10 \mathrm{wt} \%$ solids and about $8 \mathrm{wt} \%$ organics. The comparison showed SCWO costs for treatment of the $8 \mathrm{wt} \%$ organics approximately the same as incineration of $100 \%$ organic wastes.

A more detailed and applicable study compared 11 technologies for treatment of DOE mixed waste. ${ }^{\mathrm{A}-3}$ Costs were estimated for treatment systems that would treat the full spectrum of DOE mixed wastes and were based on a feed rate of $2,000 \mathrm{lb} / \mathrm{hr}$ of waste to the main treatment unit. The SCWO unit was combined with an upstream thermal desorption unit with only the desorbed organic liquids treated by SCWO. The SCWO throughput is in the $15-20 \%$ range. In the Phase 2 study that compared nine systems, the 20-year life cycle costs for seven of the systems fell within $7 \%$ of each other. Table A-2 shows cost estimates from this study.

Table A-2. Cost estimates for treatment of DOE mixed waste (from Reference A-3).

\begin{tabular}{|c|c|c|c|c|c|}
\hline Treatment system & $\begin{array}{c}\text { Demonstratio } \\
\text { costs }^{\mathrm{a}} \\
(\$ \mathrm{M})\end{array}$ & $\begin{array}{l}\text { onstruction } \\
\text { costs } \\
(\$ M)\end{array}$ & $\begin{array}{l}\text { Operating } \\
\text { costs } \\
(\$ \mathrm{M} / \mathrm{yr})\end{array}$ & $\begin{array}{l}\text { Total } \\
\text { initial } \\
\text { costs }^{\mathrm{b}} \\
(\$ \mathrm{M})\end{array}$ & $\begin{array}{l}\text { Life } \\
\text { cycle } \\
\text { costs } \\
(\$ M)\end{array}$ \\
\hline Slagging rotary kiln & 100 & 227 & 60.9 & 661 & 1,926 \\
\hline Plasma furnace & 101 & 247 & 66.5 & 710 & 2,090 \\
\hline Plasma gasification & 84 & 239 & 60.3 & 670 & 1,924 \\
\hline Molten salt oxidation & 73 & 275 & 72.8 & 749 & 2,260 \\
\hline Molten metal treatment & 92 & 215 & 61.7 & 628 & 1,924 \\
\hline Steam gasification & 57 & 277 & 68.2 & 665 & 2,150 \\
\hline Joule heated vitrification & 74 & 227 & 58.9 & 653 & 1,860 \\
\hline Mediated electrochemical oxidation & 65 & 238 & 63.8 & 633 & 1,983 \\
\hline Thermal desorption plus SCWO & 61 & 246 & 64.2 & 732 & 2,002 \\
\hline
\end{tabular}


While several of these systems could undergo additional process optimization to reduce costs, the estimates show the competitiveness of different alternatives. Costs differ by at most about $20 \%$, and on the whole SCWO does not show large advantages. Thus, referring to Table A-1, dilution to even a 5\% organic concentration is likely to raise costs above alternatives. To ensure economic competitiveness in developing SCWO, a target feed composition should be set at $10-15 \%$ organics. In terms of heating value, this is equivalent to the range

$1,000-1,800 \mathrm{Btu} / \mathrm{lb}$.

\section{REFERENCES}

A-1. U.S. Department of Energy, Environmental Restoration and Waste Management Five-Year Plan, Fiscal Years 1994-1998, "Executive Summary," p. I-9.

A-2. R. B. Kidman and K. S. Tsuji, Preliminary Cost Comparison of Advanced Oxidation Processes, LA-12221-MS, June 1992.

A-3. F. Feizollahi and W. J. Quapp, Integrated Thermal Treatment System Study, Phase 1 Results, July 1994, and Draft Phase 2 Results, August 1994, EGG-MS-11211. 
Appendix B

Basis for Estimate of Required Reactor Residence Time 



\section{Appendix B}

\section{Basis for Estimate of Required Reactor Residence Time}

The required destruction efficiency for principal organic hazardous constituents is $99.99 \%$ and for polychlorinated biphenyls $99.9999 \%$. If kinetics were known for all DOE hazardous organic constituents, the required reactor residence time could be accurately determined. Because this is not the case, the required residence time is an estimate.

Table B-1 shows required residence times for several organic compounds at different temperatures and conversions. Kinetic equations were taken from Reference B-1 for methanol, Reference B-2 for methylene chloride and acetic acid, Reference B-3 for carbon monoxide, Reference B-4 for hydrogen, Reference B-5 for methane, and Reference B-6 for ammonia.

Table B-1 shows compounds that are mostly intermediates in $\mathrm{SCWO}$. At $550^{\circ} \mathrm{C}$, a residence time of 30 seconds would be sufficient for $99.99 \%$ conversion for all the compounds listed except hydrogen, methane, and ammonia. Using these kinetics as a rough guide, a residence time of 30 seconds at $550^{\circ} \mathrm{C}$ was selected as a basis for the DOE reactor. A temperature allowance of $50^{\circ} \mathrm{C}$ (to $600^{\circ} \mathrm{C}$ ) was specified to ensure adequate conversion in light of (a) the uncertainties in the above kinetics, (b) the wide range of DOE waste constituents for which kinetics are not known, (c) the need to achieve a conversion of $99.9999 \%$ for PCBs, (d) possible future requirements for other hazardous organics that would be more stringent than $99.99 \%$, and (e) destruction of intermediates that are not accounted for in the above kinetic calculations.

Data from Sandia National Laboratories for a group of waste constituents more representative of DOE wastes provide an additional guide for selecting the reactor residence time. Conversion versus temperature and residence time was obtained for methanol, ethylene glycol, phenol, methyl ethyl ketone, acetic acid, methylene chloride, trichloromethane, latex paint, the herbicide Roundup, and a commercial motor oil, Castrol GTX 20W/50. ${ }^{\mathrm{B}-5}$ Total organic carbon (TOC) in the effluent was measured to determine destruction efficiency. The detection limits of the TOC analyzer was approximately $1.3 \mathrm{ppm}$, thus limiting the maximum destruction efficiency to approximately $99.9 \%$ for several of the feed organics. Table B-2 presents a portion of these results. $^{\text {B-5 }}$

Sandia researchers concluded that temperatures over $530^{\circ} \mathrm{C}$ and residence times near 20 seconds afford destruction efficiencies of greater than $99.95 \%$. However, in some cases a temperature higher than $530^{\circ} \mathrm{C}$ or residence time longer than 20 seconds was required to achieve 99.9\% destruction efficiency, as seen above for ethylene glycol, phenol, acetic acid, latex paint, herbicide, and motor oil. Thus, to achieve at least $99.99 \%$ destruction efficiency for all wastes, and in some cases $99.9999 \%$, a temperature greater than $550^{\circ} \mathrm{C}$ and residence time of 30 seconds is reasonable. 
Table B-1. Residence times for an SCWO reactor.

\begin{tabular}{|c|c|c|c|c|c|c|c|c|}
\hline & \multicolumn{4}{|c|}{$\begin{array}{c}\text { Conversion }=99.99 \% \\
\text { Temperature } \\
\text { (seconds) }\end{array}$} & \multicolumn{4}{|c|}{$\begin{array}{c}\text { Conversion }=99.9999 \% \\
\text { Temperature } \\
\text { (seconds) }\end{array}$} \\
\hline & $500^{\circ} \mathrm{C}$ & $550^{\circ} \mathrm{C}$ & $600^{\circ} \mathrm{C}$ & $650^{\circ} \mathrm{C}$ & $500^{\circ} \mathrm{C}$ & $550^{\circ} \mathrm{C}$ & $600^{\circ} \mathrm{C}$ & $650^{\circ} \mathrm{C}$ \\
\hline Methanol & 244 & 5.1 & 0.2 & 0.01 & 366 & 7.7 & 0.3 & 0.01 \\
\hline Methylene chloride & 112 & 29 & 9.0 & 3.1 & 168 & 44 & 13 & 4.7 \\
\hline Acetic acid & 166 & 30 & 6.4 & 1.6 & 249 & 44 & 9.6 & 2.4 \\
\hline Carbon monoxide & 66 & 21 & 7.8 & 3.2 & 99 & 32 & 12 & 4.8 \\
\hline Hydrogen & 2,000 & 59 & 2.6 & 0.17 & 3,000 & 89 & 4.0 & 0.25 \\
\hline Methane (minutes) & 490 & 112 & 30 & 9 & 730 & 170 & 45 & 15 \\
\hline Ammonia (minutes) & 1,920 & 440 & 120 & 37 & 2,900 & 660 & 180 & 55 \\
\hline
\end{tabular}


Table B-2. Sandia test results for destruction of representative Navy wastes.

\begin{tabular}{lcccc}
\hline \multicolumn{1}{c}{ Waste } & $\begin{array}{c}\text { Temperature } \\
\left({ }^{\circ} \mathrm{C}\right)\end{array}$ & $\begin{array}{c}\text { Residence time } \\
\text { (Seconds) }\end{array}$ & $\begin{array}{c}\text { Fraction } \\
(\text { TOC) }\end{array}$ & $\begin{array}{c}\text { Destruction } \\
\text { efficiency } \\
(\%)\end{array}$ \\
\hline Methanol & 538 & 12.8 & 0.00097 & 99.9 \\
Ethylene glycol & 505 & 28.0 & 0.0055 & 99.45 \\
Ethylene glycol & 517 & 16.3 & 0.009 & 99.1 \\
Ethylene glycol & 552 & 17.8 & 0.0018 & 99.82 \\
Phenol & 533 & 24.7 & 0.018 & 98.2 \\
Phenol & 575 & 12.8 & 0.00067 & 99.93 \\
Phenol & 575 & 19.1 & 0.0026 & 99.74 \\
MEK & 517 & 24.3 & 0.012 & 98.8 \\
MEK & 568 & 7.7 & 0.004 & 99.6 \\
Acetic acid & 533 & 20.5 & 0.0059 & 99.41 \\
Latex paint & 550 & -2 & - & 99.47 \\
Herbicide & 555 & -12 & 0.0031 & 99.69 \\
Motor oil & 567 & -12 & 0.00084 & 99.91 \\
Motor oil & 592 & -12 & 0.0025 & 99.75 \\
\hline
\end{tabular}




\section{REFERENCES}

B-1. J. W. Tester, P. A. Webley, H. R. Holgate, "Revised Global Kinetic Measurements of Methanol Oxidation in Supercritical Water," Industrial and Engineering Chemistry, Research, 32, 1993, pp. 236-239.

B-2. J. C. Meyer, Oxidation Chemistry and Kinetics of Model Compounds in Supercritical Water: Glucose, Acetic Acid, and Methylene Chloride, AD-A266 544, June 1993.

B-3. R. K. Helling and J. W. Tester, "Oxidation Kinetics of Carbon Monoxide in Supercritical Water," Journal of Energy and Fuels, 1, 1987, pp. 417-423,

B-4. H. R. Holgate and J. W. Tester, "Fundamental Kinetics and Mechanism of Hydrogen Oxidation in Supercritical Water," Combustion Science and Technology, 88, 1993, p. 389.

B-5. S. F. Rice, R. R. Steeper, C. A. LaJeunesse, Destruction of Representative Navy Wastes Using Supercritical Water Oxidation, SAND94-8203, October 1993.

B-6. P. A. Webley, J. W. Tester, H. R. Holgate, "Oxidation Kinetics of Ammonia and AmmoniaMethanol Mixtures in Supercritical Water in the Temperature Range $530-700^{\circ} \mathrm{C}$ at 246 Bar," Industrial and Engineering Chemistry, Research, 30, 1991, pp. 1745-1754.

B-7. C. K. Rofer and G. E. Streit, Kinetics of Methane Oxidation in Supercritical Water, LA-11439-MS, October 1988. 
Appendix C

Method Used in Critical Velocity Calculations 


\section{Appendix C}

\section{Method Used in Critical Velocity Calculations}

The critical velocity calculations made in this report were done using the following equation, taken from Reference C-1:

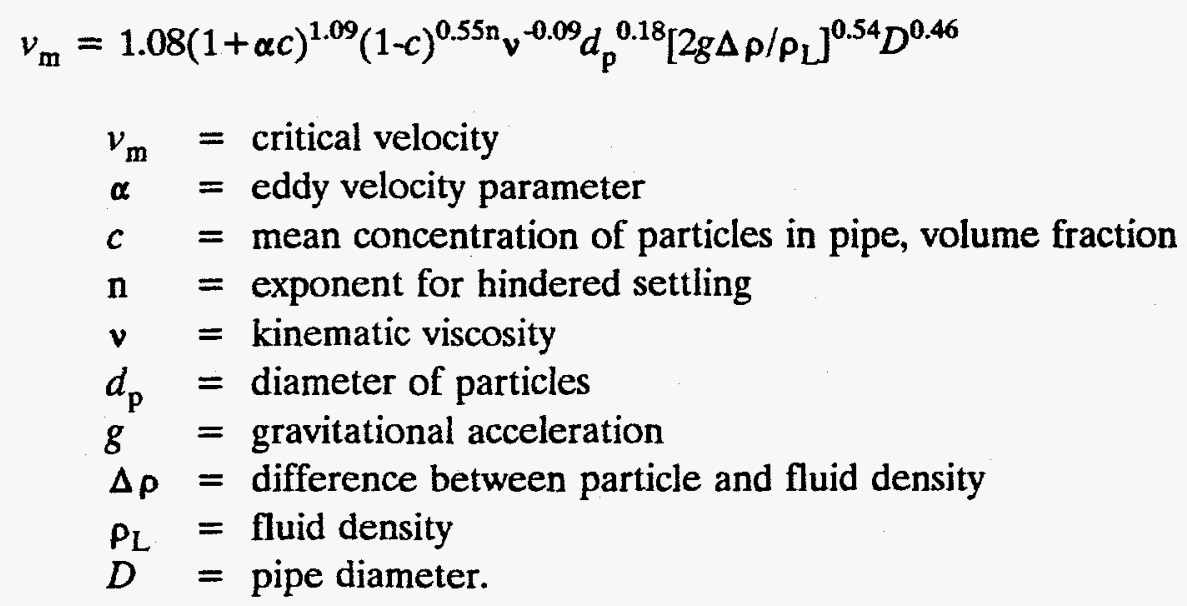

The above critical velocity equation is derived from equating the sedimentation force on particles in flowing fluid to the eddy fluctuation force, with a correction for damping of turbulence energy by the suspended particles. Comparisons of the above correlation with experimental data are given in References C-1 and C-2. Most of this data is for slurries at ambient temperatures of coal in water, sand in water, sand in ethylene glycol, iron in kerosene, limestone in water, and potash in brine. The equation is an empirical relationship (see Reference C-2) for which a theoretical basis has been provided (see Reference C-1). However, it's validity for supercritical fluids has not been determined.

\section{REFERENCES}

C-1. J. T. Davies, "Calculation of Critical Velocities to Maintain Solids in Suspension in Horizontal Pipes," Chemical Engineering Science, 42, 1987, pp. 1667-1670.

C-2. A. R. Oroskar and R. M. Turian, "The Critical Velocity in Pipeline Flow of Slurries," AIChE Journal, 26, 1980, pp. 550-558. 